\title{
Mineralogical, Geochemical, and Rock Mechanic Characteristics of Zeolite-Bearing Rocks of the Hatrurim Basin, Israel
}

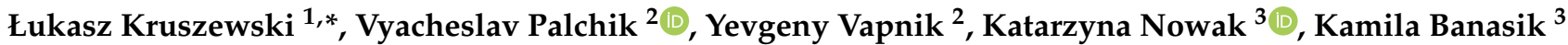 \\ and Irina Galuskina ${ }^{3}$ (D)
}

1 Institute of Geological Sciences, Polish Academy of Sciences, Research Centre in Warsaw, Twarda 51/55, 00-818 Warszawa, Poland

2 Department of Geological and Environmental Sciences, Ben-Gurion University of the Negev, P.O. Box 653, Beer-Sheva 84105, Israel; vplachek@bgu.ac.il (V.P.); vapnik@bgu.ac.il (Y.V.)

3 Institute of Earth Sciences, Faculty of Natural Sciences, University of Silesia, Będzińska 60, 41-200 Sosnowiec, Poland; katarzyna009b@interia.pl (K.N.); kamila.banasik@us.edu.pl (K.B.); irina.galuskina@us.edu.pl (I.G.)

* Correspondence: lkruszewski@twarda.pan.pl; Tel.: +48-697-8717

check for updates

Citation: Kruszewski, Ł.; Palchik, V.; Vapnik, Y.; Nowak, K.; Banasik, K.; Galuskina, I. Mineralogical,

Geochemical, and Rock Mechanic Characteristics of Zeolite-Bearing Rocks of the Hatrurim Basin, Israel. Minerals 2021, 11, 1062. https:// doi.org/10.3390/min11101062

Academic Editors: Fernando Rocha and Mazen Alshaaer

Received: 26 August 2021

Accepted: 23 September 2021

Published: 28 September 2021

Publisher's Note: MDPI stays neutral with regard to jurisdictional claims in published maps and institutional affiliations.

Copyright: (c) 2021 by the authors. Licensee MDPI, Basel, Switzerland. This article is an open access article distributed under the terms and conditions of the Creative Commons Attribution (CC BY) license (https:/ / creativecommons.org/licenses/by/ $4.0 /)$.

\begin{abstract}
The Hatrurim Basin, Israel, is located on the western border of the Dead Sea Transform. This is one of the localities of a unique pyrometamorphic complex whose genesis remains problematic. This paper deals with zeolite-bearing rock that is known in the Hatrurim Basin only. The strata subjected to zeolitization is called the "olive unit" and consists of anorthite-pyroxene (diopside-esseneite) hornfels. Zeolitization occurred in an alkaline environment provided by the interaction of meteoric water with Portland-cement-like rocks of the Hatrurim Complex. The resulting zeolite-bearing rocks contain $20-30 \%$ zeolitic material. The main zeolitic minerals are calcic: thomsonite-Ca $\pm \mathrm{Sr}$, phillipsite-Ca, gismondine-Ca, and clinoptilolite-Ca. The remainder is calcite, diopsidic pyroxene, garnets (either Ti-andradite and/or hydrogrossular), and less frequently, fluorapatite, opal, and others. Their major mineralogical and chemical compositions resemble carbonated zeolite-blended Portland mortar. Rocks show different values of porosity. Their mechanical characteristics are much better for samples with porosity values below $24 \%$. The related parameters are like those of blended concretes. The minimal age of zeolitization is $5 \mathrm{Ka}$. The natural zeolite-bearing rocks are resistant to weathering in the Levant desert climate.
\end{abstract}

Keywords: natural analogs; Hatrurim Complex; pyrometamorphism; hornfels; ultra-alkaline fluid; zeolite-bearing rocks; rock mechanics

\section{Introduction}

Zeolites are generally low-temperature alteration products of volcanic and felspathic rocks. There are six major geological settings where zeolites form: alkaline saline lakes, percolating groundwater in a semi-arid climate, nearshore or deep-sea volcanoclastic rock sediments, shallow and deep burial diagenesis, low-grade metamorphic, and magmatic rocks [1-4]. Common zeolite minerals recorded in those settings are phillipsite, clinoptilolite, chabazite, erionite, mordenite, gismondine, analcime, heulandite, thomsonite, mesolite, scolecite, stilbite, laumontite, wairakite, and yugawaralite [1,2]. The diversity of zeolites is determined by chemical composition, grain size and permeability of protolith, and $\mathrm{pH}$ of flushing solution [5]. The zeolitization of protolith is radically enlarged with the increased alkalinity of the solution [6].

A classical description of the mineralogy of the Hatrurim Complex also includes zeolites [7]. In different rock types of the Hatrurim Basin, a researcher determined Carich thomsonite, phillipsite, and gismondine were the most common or rock-forming 
Ca-rich zeolites, including several chemical analyses of thomsonite-Ca and gismondineCa. Minor minerals of the Ca-rich zeolite family were identified as scolecite, mesolite, heulandite, epistilbite, gmelinite-Ca, and lévyne-Ca. Ba-zeolite, harmotome, was also reported. Analcime occurs sporadically. There is a wide diversity of zeolites in different rocks of the Hatrurim Basin. Recently, one more type locality mineral, gismondine-Sr, was approved by CNMNC-IMA [8].

In the present report, we describe the mineralogy, chemistry, and mechanical parameters of zeolite-bearing rocks sampled at Mt. Ye'elim. The occurrence of zeolite-bearing rocks in the Upper Cretaceous sedimentary cross-section of Israel, composed mainly of chalks and marls, is unusual. Zeolite-bearing rock formation occurs without any relation to volcanic or feldspathic precursors. This rock contains from 18 to 30 vol.\% of zeolites. Among them, phillipsite-Ca, gismondine-Ca, and thomsonite-Ca are predominant. The composition of the rocks makes them analogous to zeolite-blended Portland mortar. Due to the similarity of the natural zeolite rocks to carbonated zeolite-blended Portland mortars, we have studied their rock mechanical parameters. The study of these parameters is useful for the prediction of durability and mechanical stability of the latter industrial material.

\section{Geological Setting}

Zeolite-bearing rocks are common in the Hatrurim Basin, Negev Desert, Israel. The Hatrurim Basin is the largest outcrop of the Hatrurim Complex (also known as the Mottled Zone) in Israel. It covers an area of about $50 \mathrm{~km}^{2}$. The outcrops of the Hatrurim Complex are known in Israel and Jordan, near the Dead Sea Transform Fault (Figure 1A). The Hatrurim Complex is mainly composed of ultra- and high-temperature pyrometamorphic rocks metamorphosed at the conditions of sanidinite facies and products of their lowtemperature alteration [9]. Blackish- and reddish-colored ultra- and high-temperature rocks form lenses and cliffs embedded into a matrix of light-colored, low-temperature rocks. 


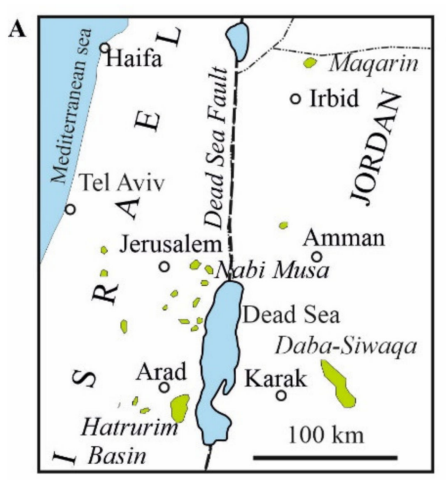

Outcrops of the Hatrurim Complex

\begin{tabular}{|c|c|c|c|c|}
\hline \multirow{2}{*}{ 这 } & Age & $\begin{array}{l}\text { Formation, } \\
\text { thickness (m) }\end{array}$ & $\begin{array}{l}\text { Normal } \\
\text { facies }\end{array}$ & $\begin{array}{l}\text { Position of } \\
\text { pyrometa- } \\
\text { morphic } \\
\text { rocks }\end{array}$ \\
\hline & Paleocene & Taqiye (30) & $\begin{array}{l}\text { Chalk } \\
\text { Marl }\end{array}$ & \multirow{2}{*}{$\begin{array}{l}\text { Hatrurim } \\
\text { Complex }\end{array}$} \\
\hline \multirow{5}{*}{ 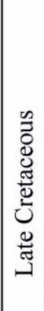 } & Maastrichtian & Ghareb (70) & Chalk & \\
\hline & Campanian & Mishash (80) & $\begin{array}{l}\text { Phosphorite } \\
\text { Chert } \\
\text { Chalk }\end{array}$ & $\begin{array}{l}\text { Phosphorite } \\
\text { Chert } \\
\text { Chalk }\end{array}$ \\
\hline & Santonian & \multirow{2}{*}{ Menuha (50) } & \multirow[t]{2}{*}{ Chalk } & \multirow[t]{2}{*}{ Chalk } \\
\hline & Coniacian & & & \\
\hline & Turonian & Bina (70) & $\begin{array}{l}\text { Limestone } \\
\text { Dolomite }\end{array}$ & $\begin{array}{l}\text { Limestone } \\
\text { Dolomite }\end{array}$ \\
\hline & Cenomanian & Tamar (30) & $\begin{array}{c}\text { Limestone } \\
\text { Dolomite }\end{array}$ & $\begin{array}{l}\text { Limestone } \\
\text { Dolomite }\end{array}$ \\
\hline
\end{tabular}
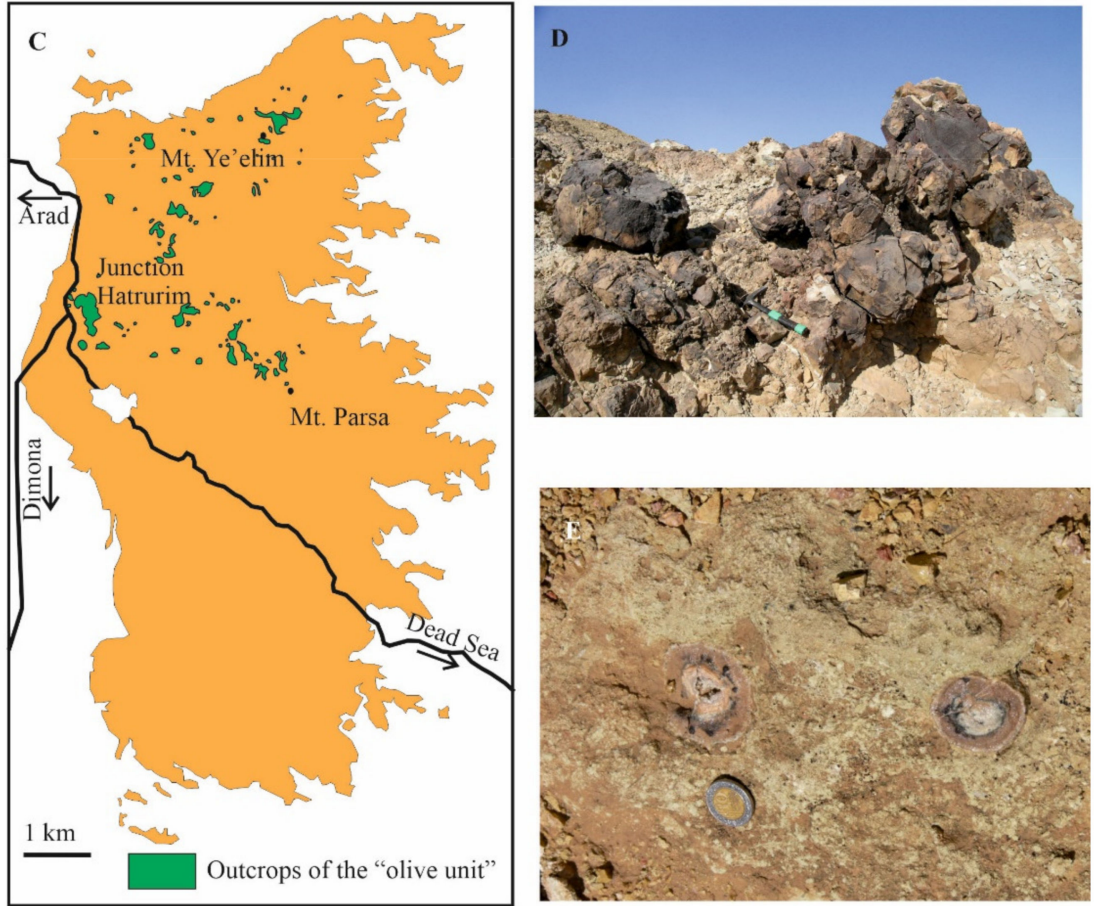

Figure 1. Geographical position of the study area. (A)-Outcrops of the Hatrurim Complex in Israel and Jordan; (B) - general schematic stratigraphic position of the Hatrurim Complex in the Late Cretaceous-Paleogene sequence of Israel $[7,10]$; (C) - the outcrops of the "olive unit" in the Hatrurim Basin [11]. The schematic locality of Mt. Ye'elim is shown; (D)-brecciated cliff of fresh anorthite-pyroxene hornfels, the "olive unit". (E)-Zeolite-bearing rock with typical zonal barite concretions. The size of coin is $2.25 \mathrm{~cm}$.

The main types of high-temperature rocks are represented by spurrite, gehlenite, larnite marbles, and anorthite-pyroxene hornfelses. Low-temperature rocks are mainly composed of calcium hydro-silicates and carbonates. Lenses of high-temperature rocks (spurrite-bearing ones) are, in some cases, huge, up to $12 \mathrm{~m}$ in thickness and up to a $200 \mathrm{~m} \times 200 \mathrm{~m}$ plane. In old quarries, the continuous thickness of spurrite-bearing rocks can be more than $30 \mathrm{~m}$.

The common temperature of metamorphism was in the range of $600-900{ }^{\circ} \mathrm{C}$. However, the revealing of numerous types of paralavas and direct study of melt inclusions indicated that the local temperatures were as high as $1200-1450{ }^{\circ} \mathrm{C}$ [12]. Thus, the typical appearance of the outcrops bears a resemblance to multi-colored hummocky relief, from which originated the second term describing the Hatrurim Complex: the Mottled Zone. 
The Mottled Zone is classified as a pyrometamorphic complex. One of the most popular hypotheses of its genesis [13] is the combustion of dispersed organic matter in the chalky-marly sequence of the Maastrichtian and Paleocene Age (Figure 1B). Fascinating mineralogical assemblages in rocks and their weathering products account for more than 240 mineral species. Most of them are rare or extremely rare, the Hatrurim Basin being the type locality for more than $20 \%$ of them (e.g., [14-16]).

According to field observations, the thickest-ca. $100 \mathrm{~m}$-pyrometamorphic crosssection, composed mainly of the chalky Ghareb and chalky-marly Taqiye Formations, is preserved in the Hatrurim Basin (Figure 1B,C). Due to its mainly greenish color, the metamorphosed equivalent of the Taqiye Formation is locally termed the "olive unit" (Figure 1C). It is not recognized in other outcrops of the Hatrurim Complex. It predominantly covers the tops of the highest hills in the Hatrurim Basin (Figure 2) [17]. The outcrops are up to a few hundred square meters $10-30 \mathrm{~m}$ in thickness. According to a geochemical comparison, the olive pyrometamorphic rocks correlate to lower marly members of the Taqiye Formation [18]. The Taqiye Formation shows a uniform lithological character with gypsum veins, pyrite, and baryte concretions. Its detrital clay assemblages are composed of montmorillonite (40-80\%), kaolinite (20-50\%), and illite (0-20\%) [19].

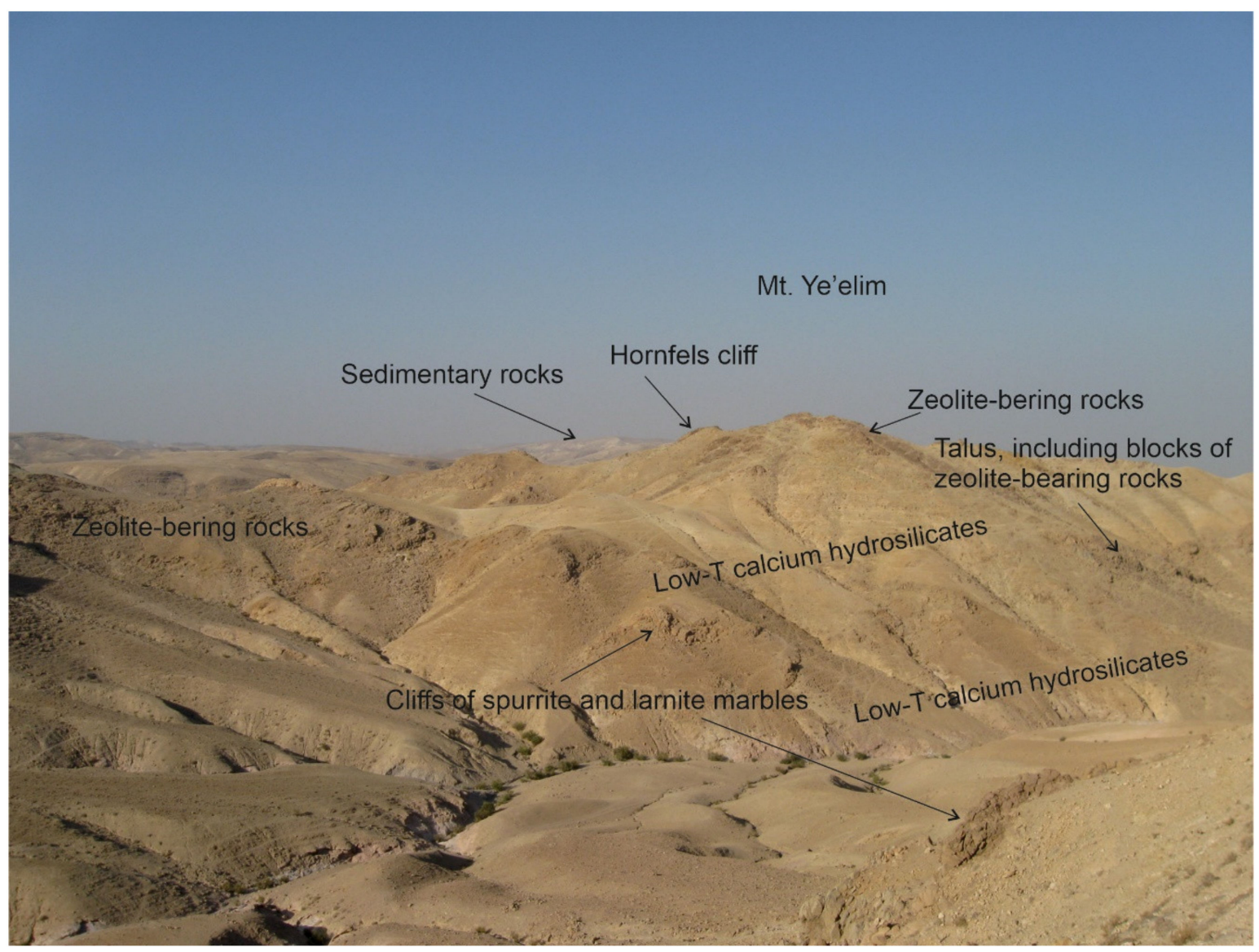

Figure 2. The Hatrurim Basin, Mt. Ye'elim, eastern slope composed of pyrometamorphic rocks and products of their alteration. Relative height of Mt. Ye'elim is about $80 \mathrm{~m}$. Ordinary sedimentary rocks are seen in the background.

The pyrometamorphic equivalent of the marly sequence of the Taqiye Formation is commonly composed of anorthite-pyroxene hornfels (Figure 1D), with ferrite segregations, baryte concretions, enclaves of coarse-grained pyrometamorphic rocks, glassy and/or vesicular-like paralavas, and low-temperature zeolite-bearing rocks. According to the glass composition of paralavas and corundum-hematite pairs revealed in ferrite 
enclaves, temperatures of pyrometamorphism of the olive unit were locally as high as $1000-1200{ }^{\circ} \mathrm{C}[20,21]$.

Several types of rocks compose the olive unit, whereas the process of zeolitization is chiefly related to anorthite-pyroxene hornfels. Anorthite, diopside-hedenbergite, gehlenite with grossular and vesuvianite or wollastonite were previously determined in hornfels of the olive unit [7].

In several cases, pyrometamorphic rocks of the olive unit are completely replaced by zeolite-bearing rocks. The zeolitization looks like a mantle topping several hills in the northern part of the Hatrurim Basin (Figure 2). Rare cliffs indicate that the zeolitized zones are at least a few meters thick. Zeolitic rocks are easily recognized by their light yellow color and porous texture of the fresh surface, whereas outcrops show brown or reddish patina. Baryte concretions up to $10 \mathrm{~cm}$ across and hematite nodules up to a few $\mathrm{cm}$ across are common (Figure 1E).

In a row of outcrops, there are recognizable relics of the high-temperature rocks within the zeolite-bearing zone of alteration. Gradual conversions of high-temperature rocks into the zeolite-bearing ones are common. Some cliffs of the anorthite-pyroxene hornfels are rather fresh and almost not subjected to zeolitic alteration.

According to ${ }^{40} \mathrm{Ar} /{ }^{39} \mathrm{Ar}$ dating on whole-rock, acid-insoluble residue fractions, and a gehlenite mineral separate, the major combustion event occurred in Israel around $3 \mathrm{Ma}[22] .{ }^{230} \mathrm{Th}-{ }^{234} \mathrm{U}$ dating was performed of carbonate-bearing veins in spurrite and gehlenite marbles. The ages of most veins are in the 250-30 Ka range. Isotopic data on $\delta^{13} \mathrm{C}$ $\left(-18 \%\right.$ to $-5 \%$ o and ${ }^{87} \mathrm{Sr} /{ }^{86} \mathrm{Sr}(0.70786-0.70811)$ ratios indicate the interaction of meteoric waters with pyrometamorphic rocks during the formation of carbonate veins [23].

The range of carbonate veins ages roughly corresponds to intensive weathering in the southern Levant during interglacial periods [24]. If the similar process and ages are correct, then the youngest limits of the zeolitization process are about $30 \mathrm{Ka}$. It is not excluded that the zeolitization may be related to wet climatic conditions in the Dead Sea basin between 6.3 and $3.3 \mathrm{Ka} \mathrm{BP}[25]$.

The zeolite-bearing blocks, such as dimension stones, from the talus slope of Mt. Ye'elim (Figure 2) have been selected for the present study. The chemical, mineralogical, and rock mechanic parameters were obtained on homogeneous parts of blocks deficient in the baryte concretions and hematite nodules.

\section{Methods}

Major and trace elements were analyzed at Acme Analytical Laboratories (Vancouver) Ltd., Shaughnessy, BC, Canada, using procedures 4A-4B and 1DX for chlorine. The preliminary mineral composition of zeolite rocks and associated minerals were examined using a Phenom XL SEM (scanning electron microscope) with an energy-dispersive Xray spectrometer (Institute of Earth Sciences, Faculty of Natural Sciences, University of Silesia, Sosnowiec, Poland), i.e., SEM-EDS. Quantitative chemical analyses of minerals were carried out on a CAMECA SX100 electron-microprobe (EPMA) apparatus (The Polish Geological Institute-National Research Institute, Warsaw, Poland) at $15 \mathrm{kV}$ and $20 \mathrm{nA}$, beam size $-2 \mu \mathrm{m}$ and the following lines and standards: TiK $\alpha$-rutile; $\mathrm{SiK} \alpha$ and $\mathrm{CaK} \alpha-$ wollastonite; $\mathrm{AlK} \alpha$ and $\mathrm{KK} \alpha$-orthoclase; $\mathrm{NaK} \alpha$-albite; $\mathrm{FeK} \alpha$-hematite; $\mathrm{CrK} \alpha-\mathrm{Cr}_{2} \mathrm{O}_{3}$; $\mathrm{MgK} \alpha$-dolomite; $\mathrm{MnK} \alpha$-rhodonite; $\mathrm{SrL} \alpha-\mathrm{SrSO}_{4} ; \mathrm{BaL} \alpha-\mathrm{BaSO}_{4} ; \mathrm{FK} \alpha$-apatite.

Powder X-Ray Diffraction (PXRD)—the major phase analysis tool—was used to obtain information about mineralogical composition of the rocks. The analyses were performed using a Bruker AXS D8 Advance diffractometer at the Clay Minerals Laboratory, Institute of Geological Sciences, Polish Academy of Sciences, Kraków, Poland. The diffractometer was equipped with a superfast LPS (linear-position-sensitive) VÅNTEC-1 detector. The radiation was $\mathrm{CoK} \alpha$, filtered and not monochromatized. The 3-80 $2 \theta$ range was scanned, with 0.02 increment; $1 \mathrm{~s}$ per step counting time was used (in the scintillation detector language; equivalent of $416 \mathrm{~s}$ per step in the LPS detector language). Unit-cell parameters and crystallite size were refined using the Rietveld method ([26]) in the Topas software (v. 4.0). 
Correctness of the approach used was verified by the attendance of one of us (Ł.K.) in Topas course, Rietveld Mailing List, and the Reynolds Cup 2018 competition.

To support the above chemical and mineralogical research, Raman Spectroscopy was also applied. The Raman spectra were recorded on a WITec alpha 300R Confocal Raman Microscope (Institute of Earth Science, Faculty of Natural Sciences, University of Silesia, Sosnowiec, Poland) equipped with an air-cooled solid laser $488 \mathrm{~nm}$ or $532 \mathrm{~nm}$ and a CCD camera operating at $-61^{\circ} \mathrm{C}$. The laser radiation was coupled to a microscope through a single-mode optical fiber with a diameter of $3.5 \mu \mathrm{m}$. An air Zeiss LD EC Epiplan-Neofluan DIC (100/0.75NA) objective was used. Raman scattered light was focused on a broad band single-mode fiber with effective pinhole size about $30 \mu \mathrm{m}$ and monochromator with a $600 \mathrm{~mm}^{-1}$ grating. Integration times of $3 \mathrm{~s}$ to $5 \mathrm{~s}$ with accumulation of 10-20 scans and a resolution ca. $3 \mathrm{~cm}^{-1}$ were chosen. The monochromator was calibrated using the Raman scattering line of a silicon plate $\left(520.7 \mathrm{~cm}^{-1}\right)$.

Mechanical properties of sixty-three zeolite samples were defined at Rock Mechanics Laboratory (Ben-Gurion University, Be'er Sheva, Israel). All samples were oven-dried prior to testing at the temperature of $105^{\circ} \mathrm{C}$ for $24 \mathrm{~h}$. Twenty-three samples were used for point load tests, twenty-three samples for tensile (Brazilian) tests, seven samples were subjected to uniaxial and triaxial compression, and ten were exploited for definition of grain density. Point load index $\left(\mathrm{I}_{\mathrm{d}}\right)$ and tensile (Brazilian) strength $\left(\sigma_{t}\right)$ were measured by using a standard Point load/uniaxial Tester (SBEL model PLT-75) equipped with hydraulic hand pump (with pressure capability of $70 \mathrm{MPa}$ ) and gauge for measurement of applied axial load. A stiff load frame (Terra-Tek, model FX-S-33090) was used for definition of peak axial stress $\left(\sigma_{1 \mathrm{p}}\right)$ of rock samples under compression. The frame utilizes a closed-loop, servo-controlled hydraulic system with maximum axial force of $1.4 \mathrm{MN}$ and stiffness of $5 \times 10^{9} \mathrm{~N} / \mathrm{m}$ [27]. The elastic modulus (E) and Poisson's ratio $(v)$ were calculated using linear regression along the liner segment of the compressive stress-strain curve. Grain density $\left(\mathrm{p}_{\mathrm{g}}\right)$ was measured by using helium porosimeter $\mathrm{PH}-220$. We measured grain volume, and then pore volume was defined by difference between bulk volume of the sample and grain volume.

\section{Results}

4.1. Bulk Chemical Analyses of the Zeolite-Bearing Rock

The chemical analysis of zeolite-bearing samples is shown in Table 1.

Table 1. Major chemical composition of the zeolite-bearing rock (wt.\%).

\begin{tabular}{ccccc}
\hline Sample & YV760 & YV758 & YV757 & YV759 \\
\hline $\mathrm{SiO}_{2}$ & 31.20 & 31.33 & 30.67 & 31.82 \\
$\mathrm{Al}_{2} \mathrm{O}_{3}$ & 14.50 & 15.12 & 14.82 & 15.14 \\
$\mathrm{TiO}_{2}$ & 0.49 & 0.50 & 0.50 & 0.50 \\
$\mathrm{Fe}_{2} \mathrm{O}_{3}$ & 4.17 & 4.24 & 4.13 & 4.22 \\
$\mathrm{Cr}_{2} \mathrm{O}_{3}$ & 0.03 & 0.03 & 0.04 & 0.03 \\
$\mathrm{MgO}$ & 1.58 & 1.61 & 1.63 & 1.63 \\
$\mathrm{MnO}$ & 0.07 & 0.08 & 0.07 & 0.08 \\
$\mathrm{CaO}$ & 27.61 & 26.98 & 27.12 & 25.99 \\
$\mathrm{Na}{ }_{2} \mathrm{O}$ & 0.36 & 0.59 & 0.89 & 0.95 \\
$\mathrm{~K}_{2} \mathrm{O}$ & 0.09 & 0.49 & 0.59 & 0.60 \\
$\mathrm{P}_{2} \mathrm{O}_{5}$ & 0.76 & 0.85 & 0.88 & 0.82 \\
$\mathrm{LOI}$ & 16.24 & 15.77 & 16.29 & 15.75 \\
\hline $\mathrm{Total}$ & 97.10 & 97.59 & 97.63 & 97.53 \\
\hline
\end{tabular}

1_Loss on ignition.

The geochemical comparison of zeolite-bearing rock and hornfels of the olive unit is shown in Figure 3. At LOI about 15\% (a diagonal line on Figure 3), zeolite-bearing rocks show similar content of $\mathrm{SiO}_{2}$ and $\mathrm{Al}_{2} \mathrm{O}_{3}$ and enrichment in $\mathrm{CaO}$. They are also enriched 
in $\mathrm{Mn}$ and $\mathrm{Cr}$. Zeolite-bearing rocks are depleted in $\mathrm{K}_{2} \mathrm{O}, \mathrm{Sr}$, and $\mathrm{Zn}$. Depletion of $\mathrm{Ba}$ is related to the omission of baryte concretions from the analyzed matter.

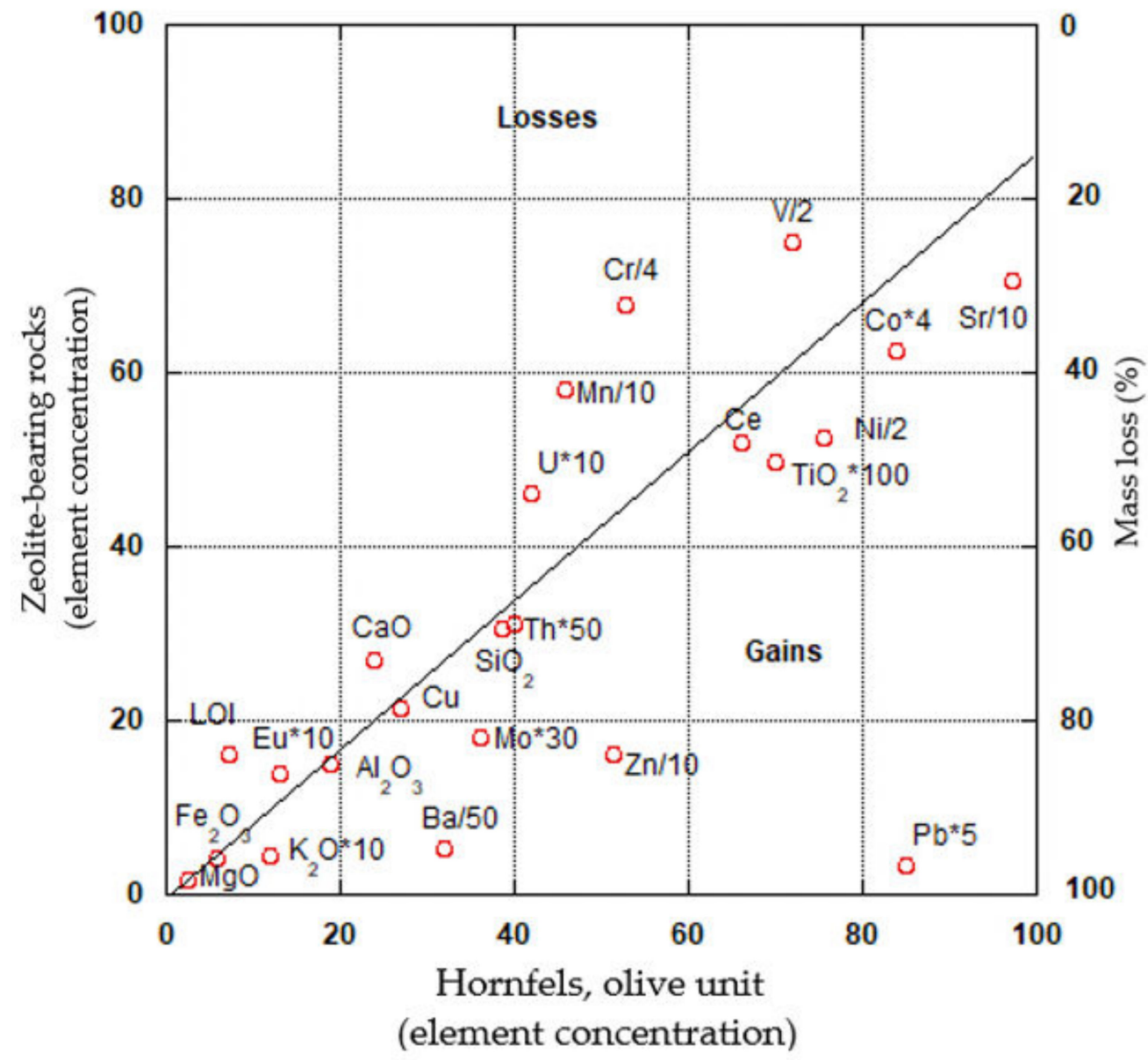

Figure 3. Isocon diagram of the zeolite-bearing rock vs. hornfels of the olive unit.

\subsection{Mineral and Chemical Composition of the Zeolite-Bearing Rock}

The PXRD analysis coupled with SEM-EDS and EPMA methods and Raman analysis allows us to unequivocally recognize the mineral composition of the studied samples. According to the PXRD phase quantitative analyses (Table 2), it was established that calcite is the dominant phase in all the studied samples, and its basal reflection has a surplus intensity due to calcite's well-known preferred orientation. This issue was corrected with the use of the March-Dollase approach. It is followed by a phase with a clinopyroxene (diopside) structure in abundance. Additionally, garnet is the main constituent in most of the samples. These three minerals account for more than $70 \%$ of the rock volume. Phillipsite-Ca, gismondine-Ca, thomsonite- $\mathrm{Ca}$, and opal are minor minerals in the studied rock. Fluorapatite, garronite-Ca, pumpellyite-group species, amesite, ferrierite-K, clintonite, clinoptilolite-Ca, and baryte are present in insignificant amounts. It should be noted that some differences in the rock composition are caused by the uneven distribution of minerals in the volume of the rock and may depend on the chosen fragment of the rock (Table 2). 
Table 2. Main minerals of the zeolite-bearing rocks and their volumes (wt.\%).

\begin{tabular}{cccccc}
\hline Constituent & YV1 & YV2 & YV3 & YV4 & Mean \\
\hline Calcite & 36.64 & 28.93 & 39.52 & 37.92 & 35.75 \\
Pyroxene (diopside) & 25.16 & 24.33 & 18.69 & 20.52 & 22.18 \\
Ti-andradite & 2.86 & 16.18 & 16.10 & 16.55 & 12.92 \\
Phillipsite-Ca & 19.02 & & 9.45 & 7.46 & 8.98 \\
Gismondine-Ca & 11.55 & 17.98 & 1.74 & & 7.82 \\
Thomsonite-Ca & & 6.03 & 10.65 & 5.87 & 5.64 \\
Opal & & 17.98 & 1.74 & & 4.93 \\
Hydrogrossular & 1.62 & 5.70 & & & 1.83 \\
Fluorapatite & 2.13 & 0.87 & & 2.98 & 1.50 \\
Garronite-Ca & & & & 5.37 & 1.34 \\
\hline
\end{tabular}

According to SEM data, calcite, opal, gismondine-Ca, thomsonite-Ca, phillipsite-Ca, and pyroxene of the diopside-esseneite series and garnet of the grossular-andradite series are the main minerals comprising the studied rocks (Figure 4).
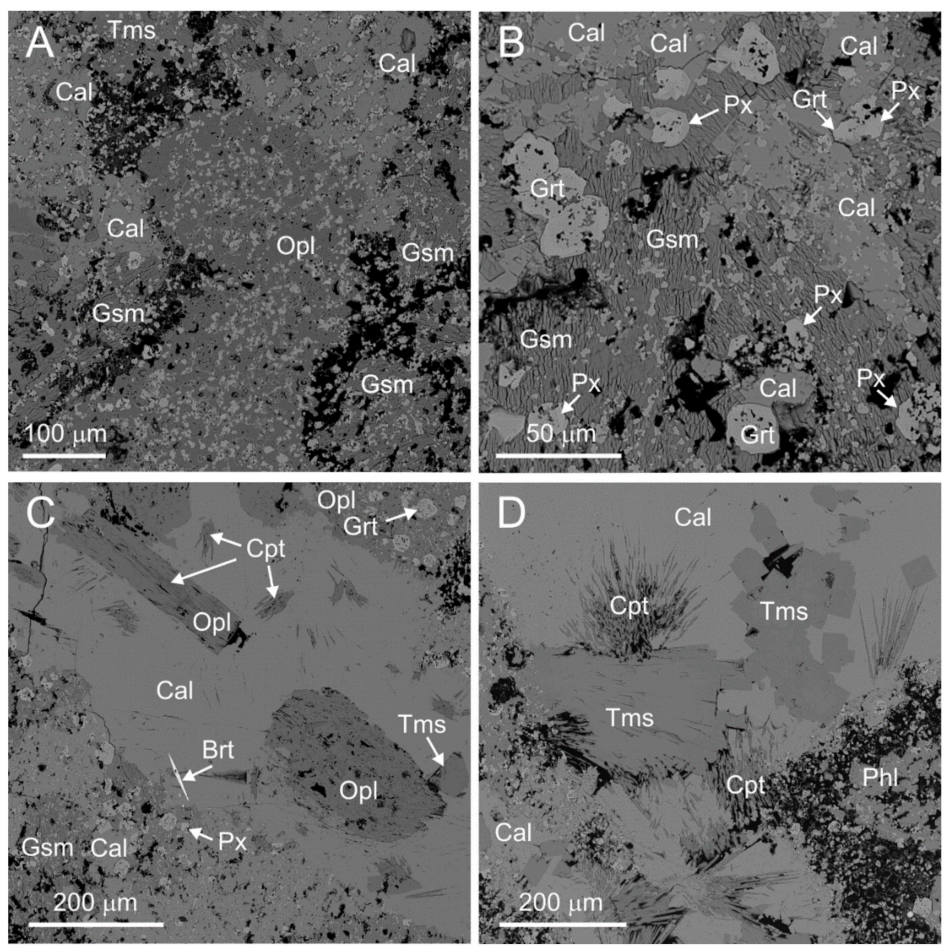

Figure 4. Mineral composition of the zeolite rock: (A)—opal, calcite, and zeolites with dissemination of garnet of the grossular-andradite series and pyroxene of the diopside-esseneite series; (B) - gismondineCa aggregates filling empties in rock; (C,D)—calcite veins containing zeolites: $(\mathbf{C})$ —clinoptilolite-Ca aggregates and pseudomorphs of opal after prismatic mineral (D) - thomsonite-Ca, clinoptilolite-Ca, and phillipsite-Ca. Brt-baryte, Cal—calcite, $\mathrm{Cpt}$-clinoptilolite-Ca, Grt-garnet of the grossular-andradite series, Gsm—gismondine-Ca, Opl—opal, Phl—phillipsite-Ca, Px-pyroxene of the diopside-esseneite series, Tms-thomsonite-Ca.

Pyroxene and garnet usually form anhedral—and very rarely euhedral—grains and crystals up to $40 \mu \mathrm{m}$ in size as a rule. It is very seldom that garnet aggregates reach about $100 \mu \mathrm{m}$. Euhedral crystals are represented by poikilitic crystals looking almost homogenous and showing the medium composition between grossular and andradite. EPMA analysis revealed that in some cases, such crystals contain a thin, irregular, discontinuous external zone slightly enriched in $\mathrm{Fe}$ and $\mathrm{Ti}$ (up to $2 \mathrm{wt} . \% \mathrm{TiO}_{2}$, Table 3). Most garnet grains are composed of Ti-bearing andradite-grossular. Often, garnet forms a core of the complex crystal, the outer part of which is represented by pyroxene of the diopside-esseneite series 
(Table 3). Fluorapatite is sporadically met in this rock; it forms skeletal crystals up to $90 \mu \mathrm{m}$ in size.

Table 3. Chemical composition of pyroxene and garnets from the zeolite-bearing rocks.

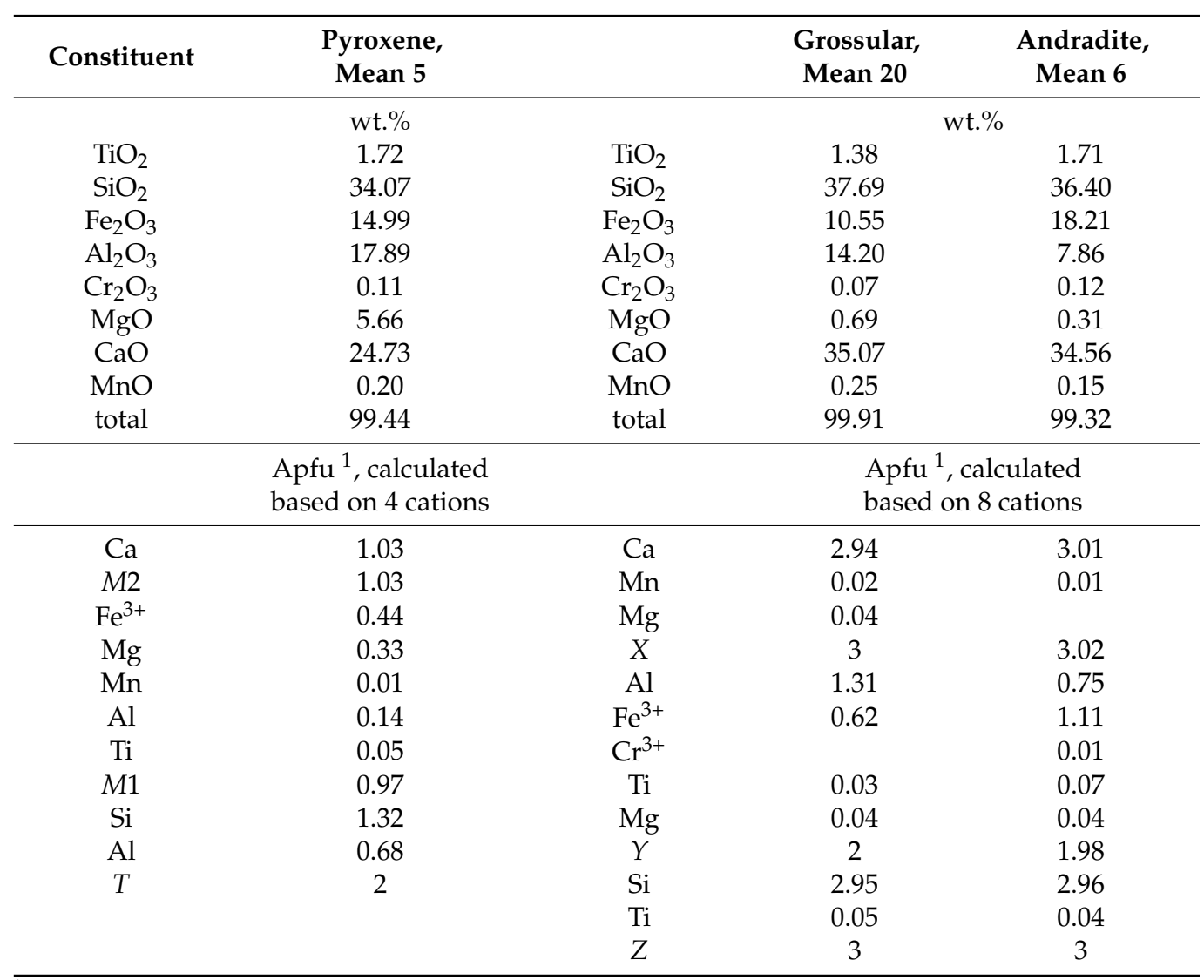

1-Atoms per formula unit.

Within the ground mass of rock, gismondine-Ca and thomsonite-Ca occur in abundance. Gismondine-Ca forms veins in the space between calcite and opal up to $70 \mu \mathrm{m}$ in thickness. Sometimes, the idiomorphic shape of gismondine-Ca crystals is visible. EPMA data for zeolites from the zeolite-bearing rock are given in Table 4.

Within the calcite veins, thomsonite-Ca and Sr-bearing thomsonite-Ca, clinoptilolite$\mathrm{Ca}$, and phillipsite-Ca are noted. Thomsonite-Ca forms idiomorphic crystals and splitting aggregates both in calcite veins and in the ground mass of rock. Aggregates of thomsoniteCa reach more than $200 \mu \mathrm{m}$ in size. Often, the internal part of the thomsonite-Ca crystal is enriched with Sr. Clinoptilolite-Ca forms radial-fibrous aggregates, the size of which do not exceed $100 \mu \mathrm{m}$. Clinoptilolite-Ca occurs only within calcite veins. Phillipsite-Ca is rather rare; it is presented by idiomorphic crystals of coarse-prismatic up to $80 \mu \mathrm{m}$ in size.

Calcite is the main mineral of the studied zeolite rocks. Its content in the rock ranges from $30 \%$ to $40 \%$ (Table 2 ). It forms fine-grained aggregates and, as a rule, fills the space between both high-T minerals (pyroxene, fluorapatite, Ti-andradite) and later minerals such as zeolites and opal. Primary calcite did not undergo changes in low-temperature late processes. A former study remarked that occasionally, secondary calcite replaces zeolites, and pseudomorphs of calcite after zeolites are observed [7]. Additionally, calcite forms veins with a thickness of $200 \mu \mathrm{m}$ to $1-2 \mathrm{~mm}$, and fills round voids $250-500 \mu \mathrm{m}$ in size.

\subsection{Raman Spectroscopy of the Main Rock-Forming Minerals and Zeolites}

Calcite, fluorapatite, opal, minerals of the grossular-andradite series and diopsideesseneite series associated with the zeolite group minerals were studied with the help of 
Raman spectroscopy (Figure 5). In the Raman spectrum of calcite, the following bands were distinguished: $156 \mathrm{~cm}^{-1}, 283 \mathrm{~cm}^{-1}, 714 \mathrm{~cm}^{-1}, 1089 \mathrm{~cm}^{-1}, 1438 \mathrm{~cm}^{-1}$, and $1751 \mathrm{~cm}^{-1}$ [28].

Table 4. Results of chemical analyses of zeolites from the zeolite-bearing rocks.

\begin{tabular}{|c|c|c|c|c|c|c|}
\hline & \multirow{2}{*}{$\begin{array}{c}\text { Gismondine-Ca } \\
\text { Mean } 26\end{array}$} & \multirow{2}{*}{$\begin{array}{c}\text { Thomsonite-Ca } \\
\text { Mean } 36\end{array}$} & \multicolumn{2}{|c|}{ Sr-Bearing Thomsonite-Ca } & \multirow{2}{*}{$\begin{array}{c}\text { Phillipsite-Ca } \\
\text { Mean } 21\end{array}$} & \multirow{2}{*}{$\begin{array}{c}\text { Clinoptilolite-Ca } \\
\text { Mean } 37\end{array}$} \\
\hline & & & Mean 27 & Mean 15 & & \\
\hline \multicolumn{7}{|c|}{ wt. $\%$} \\
\hline $\mathrm{SiO}_{2}$ & 36.88 & 36.44 & 36.68 & 34.86 & 47.67 & 67.92 \\
\hline $\mathrm{Al}_{2} \mathrm{O}_{3}$ & 30.95 & 30.71 & 30.53 & 29.69 & 26.60 & 11.16 \\
\hline $\mathrm{Fe}_{2} \mathrm{O}_{3}$ & 0.18 & 0.05 & 0.06 & 0.08 & 0.18 & 0.03 \\
\hline $\mathrm{CaO}$ & 17.73 & 13.60 & 13.05 & 11.48 & 9.19 & 4.49 \\
\hline $\mathrm{MgO}$ & 0.03 & 0.03 & & 0.01 & 0.21 & 0.25 \\
\hline $\mathrm{SrO}$ & 0.24 & 0.54 & 2.56 & 5.47 & 0.10 & 0.03 \\
\hline $\mathrm{BaO}$ & $\mathrm{bdl}^{1}$ & $\mathrm{bdl}^{1}$ & 0.12 & 0.12 & 0.16 & $\mathrm{bdl}^{1}$ \\
\hline $\mathrm{Na}_{2} \mathrm{O}$ & 0.07 & 3.66 & 3.62 & 2.87 & 0.84 & 0.19 \\
\hline $\mathrm{K}_{2} \mathrm{O}$ & 0.04 & 0.03 & 0.04 & 0.06 & 5.97 & 1.29 \\
\hline $\mathrm{H}_{2} \mathrm{O}^{2}$ & 13.92 & 13.11 & 13.19 & 12.61 & 8.88 & 13.58 \\
\hline total & 100.04 & 98.17 & 99.84 & 97.25 & 99.79 & 98.93 \\
\hline \multicolumn{7}{|c|}{ Apfu ${ }^{3}$ calculated based on: } \\
\hline & 5 cations & & 13 cations & & 10 cations & 39 cations \\
\hline $\mathrm{Ca}$ & 1.02 & 2.00 & 1.91 & 1.76 & 1.00 & 2.12 \\
\hline $\mathrm{Na}$ & 0.01 & 0.97 & 0.96 & 0.79 & 0.17 & 0.16 \\
\hline $\mathrm{K}$ & 0.00 & 0.01 & 0.01 & 0.01 & 0.77 & 0.73 \\
\hline $\mathrm{Mg}$ & & 0.01 & & & 0.03 & 0.17 \\
\hline $\mathrm{Sr}$ & 0.01 & 0.04 & 0.20 & 0.45 & 0.01 & 0.01 \\
\hline $\mathrm{Ba}$ & & & 0.01 & 0.01 & 0.01 & \\
\hline $\mathrm{Fe}^{3+}$ & 0.01 & & 0.01 & 0.01 & 0.01 & 0.01 \\
\hline $\mathrm{Al}$ & 1.96 & 4.97 & 4.91 & 4.99 & 3.18 & 5.81 \\
\hline $\mathrm{Si}$ & 1.99 & 5.00 & 5.00 & 4.98 & 4.83 & 30.00 \\
\hline $\mathrm{H}_{2} \mathrm{O}$ & 5.00 & 12.00 & 12.00 & 12.00 & 6.00 & 40.00 \\
\hline
\end{tabular}

${ }^{1}$-Below the detection limit; ${ }^{2}$ - calculated on the basis of stoichiometry; ${ }^{3}$-atoms per formula unit.

The main bands in the Raman spectrum of fluorapatite are related to the symmetric stretching vibration mode of $\mathrm{PO}_{4}{ }^{3-}$ at $965 \mathrm{~cm}^{-1}$. Slightly marked bands at $890 \mathrm{~cm}^{-1}$ and $1009 \mathrm{~cm}^{-1}$, referred to as vibration modes of $\mathrm{SiO}_{4}{ }^{4-}$ and $\mathrm{SO}_{4}{ }^{2-}$, respectively, confirm an ellestadite type of substitution in the apatite-ellestadite series [29]. The vibrations visible in the lower spectral values correspond to the bending vibration of the anions in the structure of fluorapatite. Domination of the fluorine member of apatite is confirmed by a characteristic Raman shift in the symmetric and asymmetric bending modes of the main functional group and asymmetric stretching vibrations of $\mathrm{PO}_{4}{ }^{3-}$ [30].

In the opal Raman spectrum, the most prominent strong wide band is visible between the $200 \mathrm{~cm}^{-1}$ and $500 \mathrm{~cm}^{-1}$ vibration region [31]. The region between $3300 \mathrm{~cm}^{-1}$ and $3800 \mathrm{~cm}^{-1}$ is assigned to $\mathrm{O}-\mathrm{H}$ bond stretching modes of the hydrous species incorporated in the silicate matrix [32].

Raman spectra of garnet group minerals belong to the grossular-andradite series. Presented spectra show three relatively intense modes around $369 \mathrm{~cm}^{-1}, 528 \mathrm{~cm}^{-1}$, and $877 \mathrm{~cm}^{-1}$, which can be assigned to rotational (R) (i.e., librational), internal bending, and stretching vibrations of the $\mathrm{SiO}_{4}{ }^{4-}$ tetrahedra, respectively [33].

Ca-clinopyroxenes presented in the studied rock belong to the diopside-esseneite series. Their Raman spectra are characterized by intense bends region with a maximum of $988 \mathrm{~cm}^{-1}$ for the Si-O $\mathrm{O}_{\text {nbr }}$ stretching mode and $667 \mathrm{~cm}^{-1}$ for $\mathrm{Si}-\mathrm{O}_{\mathrm{br}}$ stretching bonds [34]. A slight shift to lower values as well as changes in the spectrum in the region $750-850 \mathrm{~cm}^{-1}$ are probably due to the presence of $\mathrm{Al}$ in the tetrahedral positions of these members $[34,35]$. In the $480-580 \mathrm{~cm}^{-1}$ region, bands assigned to the $\mathrm{O}-\mathrm{Si}-\mathrm{O}$ bending modes were observed, and in the lower region, bands were attributed to the cation-oxygen vibrations $[34,36]$. 


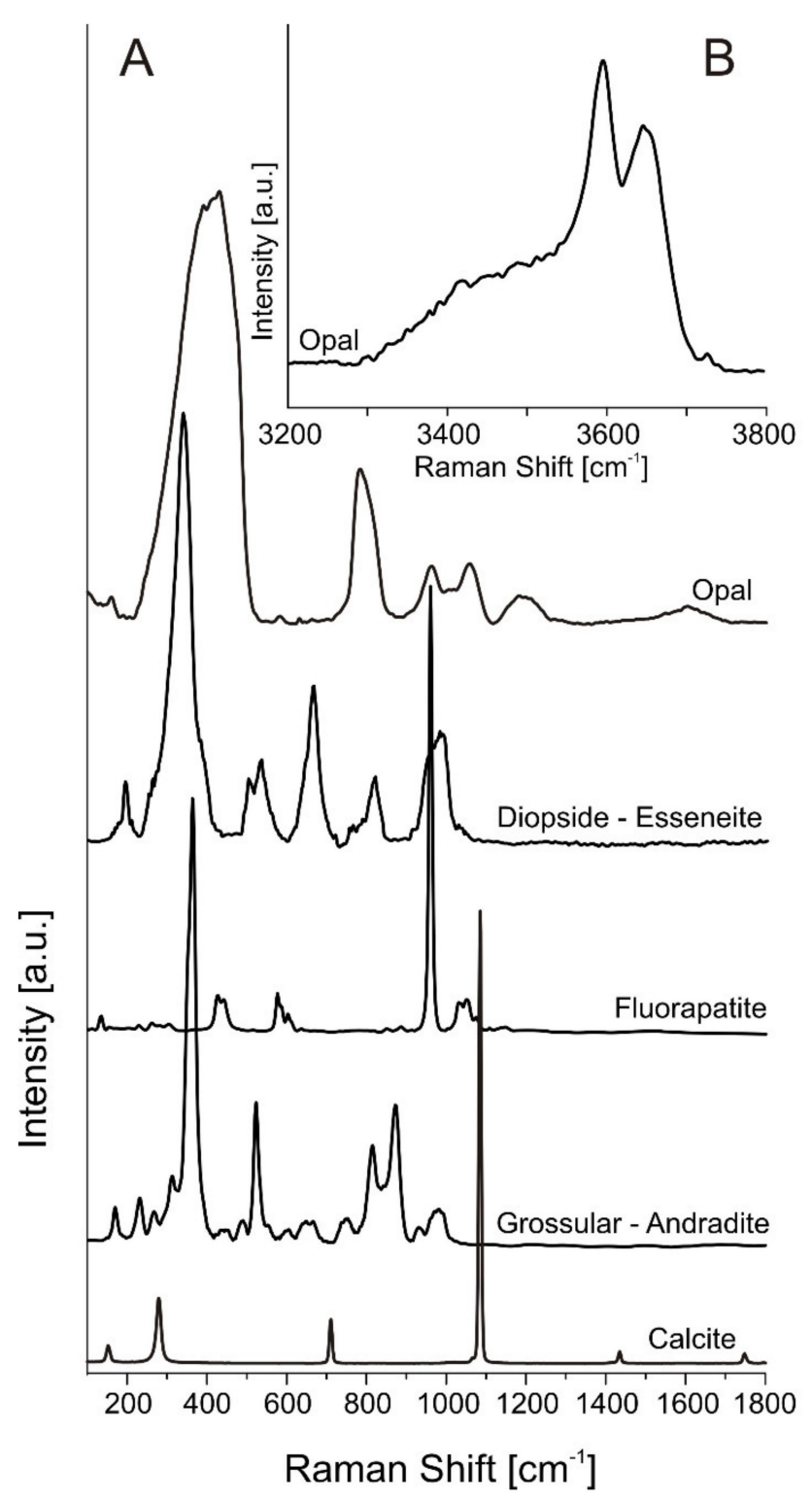

Figure 5. Raman spectrum of major mineral phases in the zeolite-bearing rock. Raman spectra of opal are represented in two figures within the range 0-1800 (A) and $3200-3800 \mathrm{~cm}^{-1}$ (B).

Raman spectra were obtained for the next minerals of the zeolite group: thomsonite-Ca, Sr-bearing thomsonite-Ca, phillipsite- $\mathrm{Ca}$, gismondine- $\mathrm{Ca}$, and clinoptiolite-Ca (Figure 6). Raman spectra of the zeolite group minerals are classified according to the general types of the fundamental modes of the coupled $T_{4}$ tetrahedra $\left(T=\mathrm{Al}\right.$ or $\mathrm{Si}$ ) and the $\mathrm{H}_{2} \mathrm{O}$ molecule. Furthermore, interpretation of the position of the ring bands depends on several factors: the number of ring members, Al:Si ratio, kind of non-tetrahedral cations, degree of ring deformation, degree of zeolite hydration, and arrangement of structure [37,38].

In the thomsonite-Ca Raman spectra, several strong and weak bands below $1100 \mathrm{~cm}^{-1}$ corresponding to the fundamental modes of $(\mathrm{Al}, \mathrm{Si}) \mathrm{O}_{4}$ tetrahedra are distinguished. Strong bands in the range between 3000 and $3800 \mathrm{~cm}^{-1}$ caused by O-H stretching mode of water in crystal structure and a weak band at $1650 \mathrm{~cm}^{-1}$ are assigned to the bending mode of water [37]. The presence of a very strong peak at $538 \mathrm{~cm}^{-1}$ is characteristic for thomsonite-Ca and scolecite within the natrolite group. Unambiguous identification between these two minerals can be easily performed considering the band region of the stretching vibration of the $\mathrm{H}_{2} \mathrm{O}$ molecules $\left(3000-3600 \mathrm{~cm}^{-1}\right.$ ). Thomsonite-Ca has a broad unresolved double peak, and scolecite has several sharp peaks in the water region [37]. 
Changes being results of substitution between $\mathrm{Ca}$ by $\mathrm{Sr}$ in the structure of thomsonite-Ca are visible in the lower wavenumbers below $535 \mathrm{~cm}^{-1}$, which relates to the higher atomic mass of strontium and its larger ionic radius in comparison of calcium. Gismondine$\mathrm{Ca}$ and phillipsite-Ca belong to the S4R group, where single four-membered rings are the basic structural elements [38]. "Breathing" vibrations of the four-membered rings are predominant in the spectra of this zeolites group, and they are visible in the range of $470-520 \mathrm{~cm}^{-1}$. Raman spectra of clinoptilolite belong to the most complicated SBU (Secondary Building Units) structure among all zeolites [39]. This type of zeolites contains two groups of bands-one in the range $390-415 \mathrm{~cm}^{-1}$, assigned to the five-membered ring vibrations, the other in the range $480-500 \mathrm{~cm}^{-1}$, connected with four-membered ring vibrations [38].

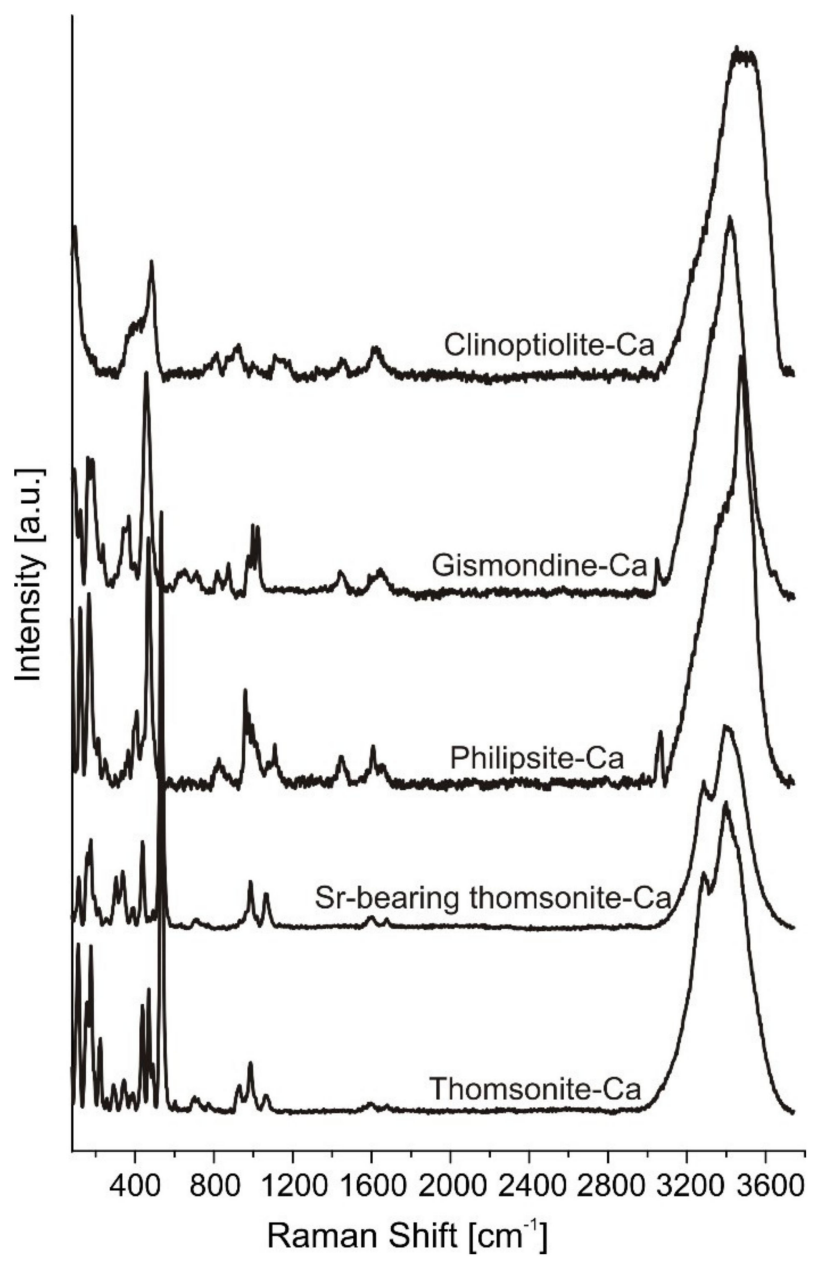

Figure 6. Raman spectra of zeolites under scope.

\subsection{Mechanical Properties of the Zeolite-Bearing Rock}

The measured mechanical parameters of the zeolite-bearing rock are presented in Tables 5 and 6 . According to the calculated values of porosity of the samples and their corresponding mechanical behavior, the rocks may be divided into two types: with porosity below $24 \%$ (between $18 \%$ and $24 \%$ ) and porosity above $24 \%$ (between $24 \%$ and $27 \%$ ). Zeolitebearing rocks are not completely homogeneous, and some samples contain amygdule-like pores. Thus, the high porosity of samples may be partly determined by the presence of amygdules. 
Table 5. Point load index $\left(\mathrm{I}_{\mathrm{d}}\right)$ and indirect (Brazilian) tensile strength $\left(\sigma_{t}\right)$ of the zeolite-bearing rocks.

\begin{tabular}{cccccc}
\hline Sample & $\boldsymbol{n}, \boldsymbol{\%}$ & $\mathbf{I}_{\mathbf{d}}, \mathbf{M P a}$ & Sample & $\boldsymbol{n}, \boldsymbol{\%}$ & $\boldsymbol{\sigma}_{\mathbf{t}}, \mathbf{M P a}$ \\
\hline $1 \mathrm{p}$ & 21.1 & 2.45 & $1 \mathrm{~b}$ & 25.8 & 2.15 \\
$2 \mathrm{p}$ & 25.4 & 1.2 & $2 \mathrm{~b}$ & 20.2 & 2.79 \\
$3 \mathrm{p}$ & 22.1 & 2.51 & $3 \mathrm{~b}$ & 23.3 & 3.4 \\
$4 \mathrm{p}$ & 20.5 & 2.22 & $4 \mathrm{~b}$ & 21.4 & 3.67 \\
$5 \mathrm{p}$ & 20.8 & 2.74 & $5 \mathrm{~b}$ & 21.9 & 3.45 \\
$6 \mathrm{p}$ & 21.8 & 0.86 & $6 \mathrm{~b}$ & 19.7 & 3.55 \\
$7 \mathrm{p}$ & 23.1 & 1.9 & $7 \mathrm{~b}$ & 21.5 & 4.1 \\
$8 \mathrm{p}$ & 24.2 & 3.32 & $8 \mathrm{~b}$ & 22.8 & 3.39 \\
$9 \mathrm{p}$ & 22.3 & 2.73 & $9 \mathrm{~b}$ & 19.1 & 3.73 \\
$10 \mathrm{p}$ & 21.6 & 2.87 & $10 \mathrm{~b}$ & 19.6 & 3.88 \\
$11 \mathrm{p}$ & 19.8 & 3.01 & $11 \mathrm{~b}$ & 19.1 & 3.4 \\
$12 \mathrm{p}$ & 18.7 & 2.22 & $12 \mathrm{~b}$ & 23.5 & 3.7 \\
$13 \mathrm{p}$ & 21.2 & 3.01 & $13 \mathrm{~b}$ & 20.3 & 3.17 \\
$14 \mathrm{p}$ & 19.9 & 2.74 & $14 \mathrm{~b}$ & 21.3 & 4.29 \\
$15 \mathrm{p}$ & 18.3 & 3.09 & $15 \mathrm{~b}$ & 24.4 & 2.93 \\
$16 \mathrm{p}$ & 23.1 & 3.14 & $16 \mathrm{~b}$ & 21.8 & 3.6 \\
$17 \mathrm{p}$ & 24.7 & 2.5 & $17 \mathrm{~b}$ & 18.4 & 3.59 \\
$18 \mathrm{p}$ & 23.6 & 3.42 & $18 \mathrm{~b}$ & 22.1 & 3.88 \\
$19 \mathrm{p}$ & 23.1 & 3.07 & $19 \mathrm{~b}$ & 24.7 & 2.33 \\
$20 \mathrm{p}$ & 22.3 & 3.25 & $20 \mathrm{~b}$ & 19.8 & 2.88 \\
$21 \mathrm{p}$ & 24.6 & 2.5 & $21 \mathrm{~b}$ & 27.1 & 1.97 \\
$22 \mathrm{p}$ & 26.1 & 1 & $22 \mathrm{~b}$ & 26.7 & 2 \\
$23 \mathrm{p}$ & 26.6 & 0.94 & $23 \mathrm{~b}$ & 27.2 & 2.1
\end{tabular}

$n$ is calculated porosity (at grain density of $\mathrm{pg}_{\mathrm{g}}=2.5 \mathrm{~g} / \mathrm{cm}^{3}$ measured by helium porosimeter $\mathrm{PH}-220$ ), $\mathrm{I}_{\mathrm{d}}$ is point load strength, $\sigma_{t}$ is indirect tensile (Brazilian) strength.

Table 6. Results of the compressive tests conducted on the zeolite-bearing rocks.

\begin{tabular}{ccccccc}
\hline Sample & $\boldsymbol{\sigma}_{\boldsymbol{3}}, \mathbf{M P a}$ & $\boldsymbol{\Delta}_{\mathbf{1} \mathbf{p}}, \mathbf{M P a}$ & $\boldsymbol{\sigma}_{\mathbf{1} \mathbf{p}}, \mathbf{M P a}$ & $\boldsymbol{n}, \boldsymbol{\%}$ & $\mathbf{E}, \mathbf{M P a}$ & $\boldsymbol{v}$ \\
\hline zeo1 & 0 & 16.5 & 16.5 & 25.6 & 5630 & 0.21 \\
zeb1a & 0 & 28.32 & 28.32 & 21.04 & 12360 & 0.22 \\
zeo2 & 1.45 & 25.5 & 26.95 & 23.9 & 6440 & 0.15 \\
zeb2a & 3.73 & 42.1 & 45.83 & 19.71 & 15260 & 0.24 \\
z3j & 1.92 & 19 & 20.92 & 25.5 & 2740 & 0.14 \\
zeo4 & 2.52 & 22.1 & 24.62 & 26.9 & 5290 & 0.12 \\
zeb4 & 0 & 21.2 & 21.2 & 20.83 & 19290 & 0.26
\end{tabular}

$\sigma_{3}$ is confining pressure, $\Delta \sigma_{1 \mathrm{p}}$ is peak stress difference, $\sigma_{1 \mathrm{p}}$ is peak axial stress, $n$ is calculated porosity (at $\mathrm{p}_{\mathrm{g}}=2.5 \mathrm{~g} / \mathrm{cm}^{3}$ measured by helium porosimeter PH-220), E is elastic modulus, and $v$ is Poisson's ratio.

Relations between the point load index $\left(\mathrm{I}_{\mathrm{d}}\right)$ and porosity $(n)$ are presented in Figure 7. The latter demonstrates that when $n<24 \%$, there is no correlation between $\mathrm{I}_{\mathrm{d}}$ and porosity $(n)$ : the squared regression coefficient is very small $\left(R^{2}=0.0063\right)$. On the other hand, there is a pronounced influence of porosity $\left(R^{2}=0.88\right)$ on the point load index $\left(\mathrm{I}_{\mathrm{d}}\right)$ when $n>24 \%: \mathrm{I}_{\mathrm{d}}$ decreases according to linear law with increasing porosity $(n)$. The same trend was obtained in Figure 8, showing dependence between porosity and indirect (Brazilian) tensile strength $\left(\sigma_{t}\right): n<24 \%$ is not correlated with $\sigma_{t}\left(R^{2}=0.0329\right)$; the effect of porosity on $\sigma_{t}$ increases $\left(R^{2}=0.75\right)$ when porosity $n>24 \%$. Hence, two different levels of porosity ( $n<24 \%$ and $n>24 \%$ ) exhibit different effects on values of the point load index $\left(\mathrm{I}_{\mathrm{d}}\right)$ and Brazilian tensile strength $\left(\sigma_{t}\right)$.

The relationship between variable $\mathrm{E}$ and $n$ for all samples shown in Table 6 is presented in Figure 9. It is clearly visible that the elastic modulus (E) increases according to logarithmic law $\left(R^{2}=0.78\right.$ is reasonable) with decreasing porosity $(n)$. The elastic modulus is a manifestation of rock stiffness, the length of grain to grain contacts, and the number of contacts per grain (textural features which directly influence rock stiffness; [40,41]). Thus, it must increase with decreasing void space. The elastic modulus is also partly dependent on mosaic texture, mineralogical composition, and pore types that influence on nature of con- 
tacts between grains in different rock types [42-44]. It is likely because of the amygdaloidal texture of some samples that the correlation between $\mathrm{E}$ and $n$ is not perfect (Figure 9).

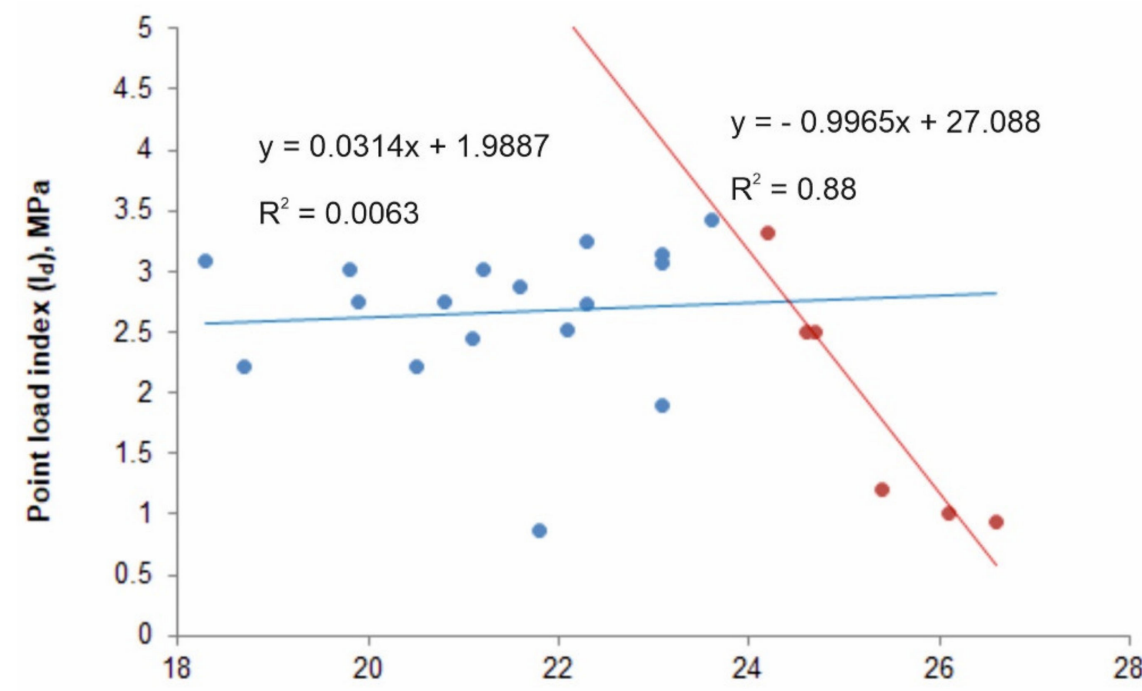

Porosity (n), \%

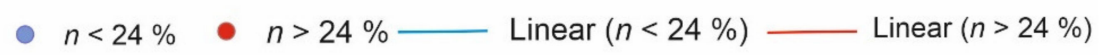

Figure 7. Relations between point load index $\left(\mathrm{I}_{\mathrm{d}}\right)$ and two different level of porosity $(n<24 \%$ and $n>24 \%$ ) for the zeolite-bearing rocks.

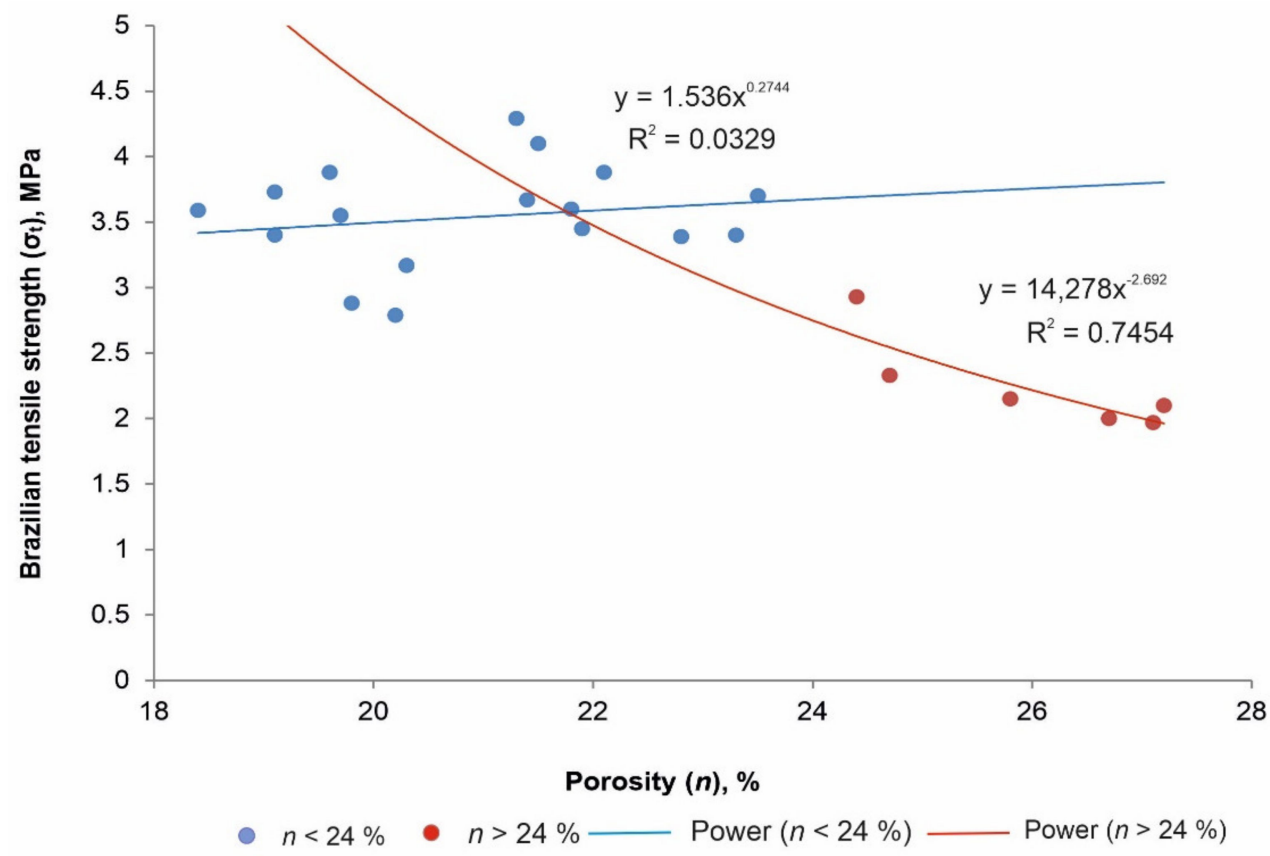

Figure 8. Relations between indirect (Brazilian) tensile strength $\left(\sigma_{t}\right)$ and two different level of porosity ( $n<24 \%$ and $n>24 \%$ ) for the zeolite-bearing rocks.

Since the porosity strongly influences the stiffness (elastic modulus E) of studied zeolite-bearing rocks, it is logical to suggest that it also influences rock strength $\left(\sigma_{1 p}\right)$. Table 7 demonstrates the compressive strength of rock samples. 


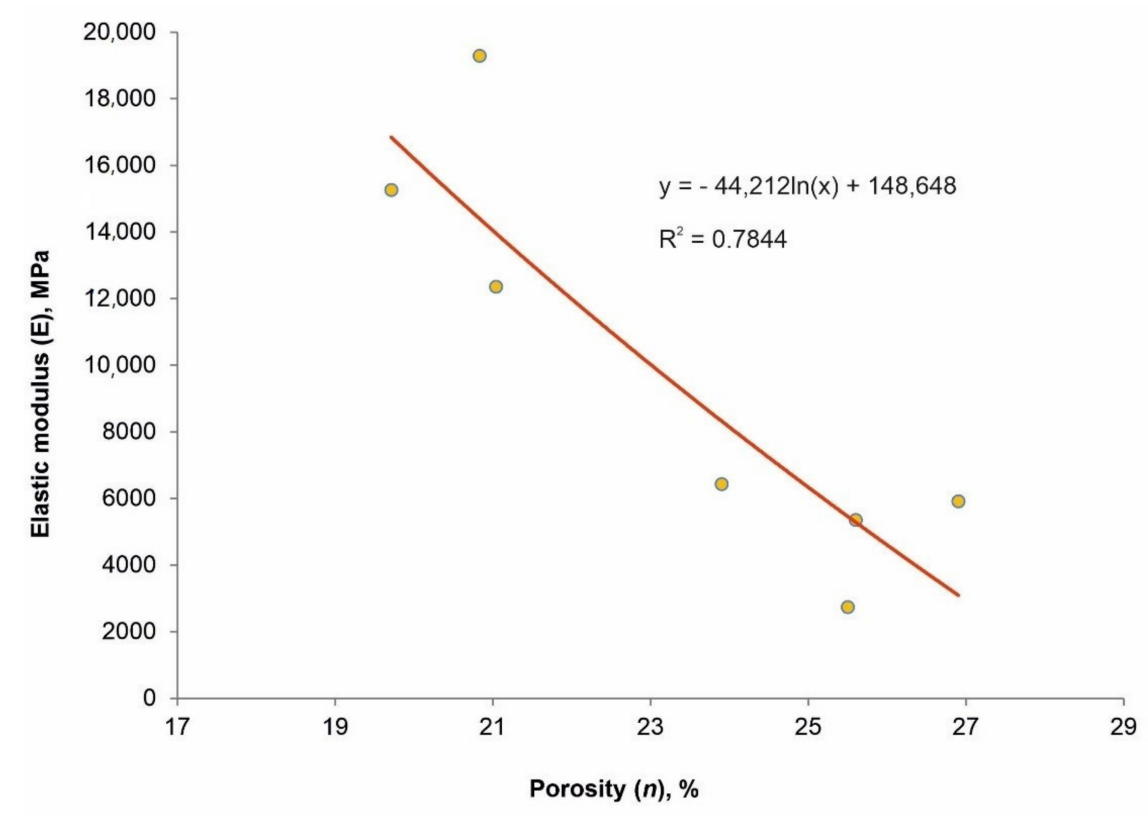

Figure 9. The relation between elastic modulus (E) and porosity $(n)$ of the zeolite-bearing rocks.

Table 7. Compressive strength of the zeolite-bearing rocks.

\begin{tabular}{|c|c|c|c|c|c|}
\hline Sample & $n, \%$ & $\sigma_{3}, \mathrm{MPa}$ & $\sigma_{1 p}, \mathrm{MPa}$ & $c, \mathrm{MPa}$ & $\Phi,{ }^{\circ}$ \\
\hline zeb4 & \multirow{4}{*}{$<24$} & 0 & 21.2 & \multirow{4}{*}{4.96} & \multirow{4}{*}{44} \\
\hline zeb1a & & 0 & 28.32 & & \\
\hline zeo2 & & 1.45 & 26.95 & & \\
\hline zeb2a & & 3.73 & 45.83 & & \\
\hline zeo1 & \multirow{3}{*}{$>24$} & 0 & 16.5 & \multirow{3}{*}{4.7} & \multirow{3}{*}{29.9} \\
\hline$z 3 j$ & & 1.92 & 20.92 & & \\
\hline zeo4 & & 2.52 & 24.62 & & \\
\hline
\end{tabular}

$n$ is calculated porosity (at $\rho_{\mathrm{g}}=2.5 \mathrm{~g} / \mathrm{cm}^{3}$ measured by helium porosimeter PH-220), $\sigma_{3}$ is confining pressure, $\sigma_{1 \mathrm{p}}$ is peak axial stress, $c$ is cohesion, and $\Phi$ is friction angle.

It is established that correlations between peak axial stress $\left(\sigma_{1 \mathrm{p}}\right)$ and confining pressure $\left(\sigma_{3}\right)\left(R^{2}=0.85\right.$ and 0.94 for $n<24 \%$ and $n>24 \%$, respectively) are linear, and, therefore, it is reasonable to use the Mohr failure criterion [45].

Figures 10 and 11 demonstrate the Mohr-Coulomb failure envelopes constructed for $n<24 \%$ and $n>24 \%$ rock porosities, respectively. The values of cohesion (c) and friction angle $(\Phi)$ defined by constructing tangents to the failure envelopes (in Figures 10 and 11) are shown in Table 7. It is obvious that an increase in the level of porosity $(n)$ leads to a decrease in values of cohesion ( $c$ decreases from 4.96 to $4.7 \mathrm{MPa}$ ) and friction angle $(\Phi$ decreases from $44^{\circ}$ to $29.9^{\circ}$ ). Cohesion $(c)$ is a measure of the inter-grain bonding strength. Lower cohesion means that grains have a lower tendency to clump or stick together. Since a higher porosity corresponds to a lower value of $c$, we may suggest that the high porosity (large void between grains) reduces the ability of grains of the studied zeolite to stick together. The angle of internal friction $(\Phi)$ shows how sample grains slide against each other. The higher the value of $\Phi$, the greater the friction between the grains. Probably, the decrease in $\Phi$ with increasing $n$ can be explained by the reduction of friction between grains due to an increase of void space between grains. The fact that the increase in porosity may lead to a decrease in friction angle is confirmed by [46-48] and [49] for some porous rocks and soils. 
It is also apparent (Table 7) that a lower porosity level corresponds to higher peak axial stress $\left(\sigma_{1 \mathrm{p}}\right)$. Indeed, a value of $\sigma_{1 \mathrm{p}}=28.32 \mathrm{MPa}\left(\right.$ at $\left.\sigma_{3}=0\right)$ for a porosity level below $24 \%$ is larger than all values of $16.5 \mathrm{MPa}<\sigma_{1 \mathrm{p}}<24.62 \mathrm{MPa}$ (at $0<\sigma_{3}<2.52 \mathrm{MPa}$ ) for a porosity level above $24 \%$.

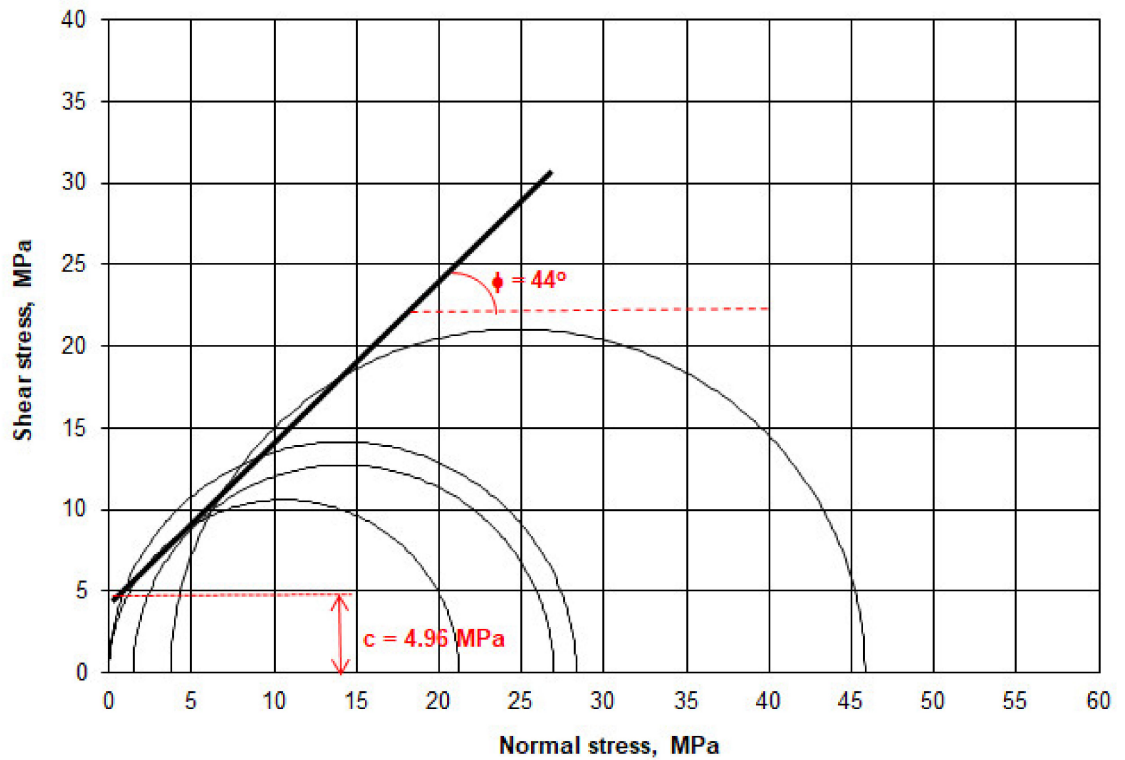

Figure 10. Mohr-Coulomb failure envelopes in terms of normal and shear stress for porosity of the zeolite-bearing rock $n<24 \%$. The tangent line is composed according to best fit between $\sigma_{1 \mathrm{p}}$ and $\sigma_{3}$. Determined parameters are $c=4.96 \mathrm{MPa}$ and $\Phi=44^{\circ}$.

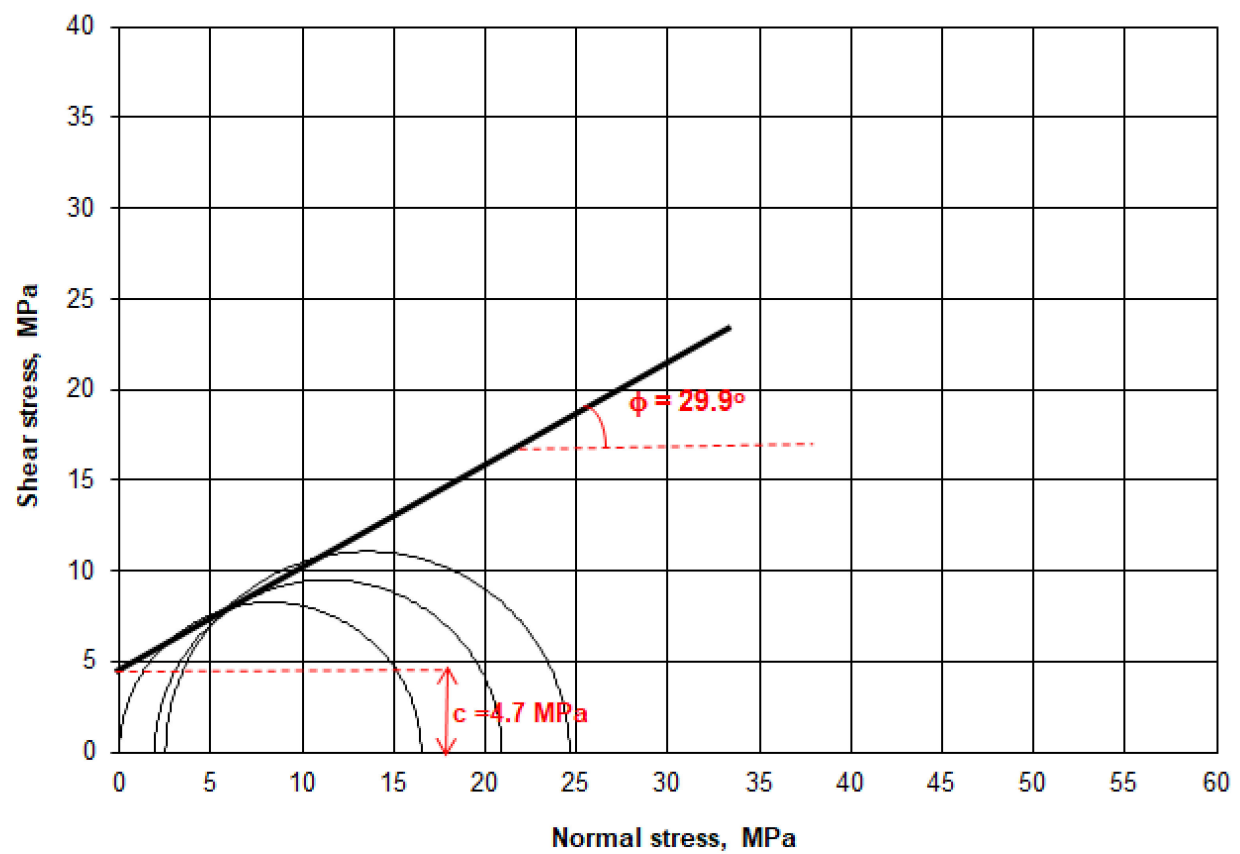

Figure 11. Mohr-Coulomb failure envelopes in terms of normal and shear stress for porosity of the zeolite-bearing rock $n>24 \%$. Determined parameters are $c=4.7 \mathrm{MPa}$ and $\Phi=29.9^{\circ}$.

\section{Discussion}

Zeolite-bearing rocks are known in the Hatrurim Basin, and their position is mainly related to the tops of mountains in the northern part of the basin. Their location was determined by the marly protolith of the Taqiye Formation. According to the geological position 
of the zeolite-bearing rocks, it is claimed that their precursor was a pyrometamorphic rock of the olive unit. There are gradual contacts between two rock types. Supporting pieces of evidence are relics of high-temperature minerals belonging to the olive unit (pyroxene of diopside-esseneite composition, grossular-andradite garnet, fluorapatite, rare grains of plagioclase, and gehlenite) and geochemical correlation between the hornfels and the zeolite-bearing rocks.

Major minerals of the unit—pyroxene and plagioclase-were subjected to the zeolitization process. The necessary conditions of high alkalinity $[50,51]$ were provided by the interaction of meteoric waters with other pyrometamorphic rock units of the Hatrurim Basin, whose mineralogical content resembles Portland cement [52]. These are mainly spurrite, larnite, and gehlenite-bearing rocks. The contemporary flow of ultra-alkaline waters with $\mathrm{pH}$ up to 12.5 is evidenced in the Maqarin pyrometamorphic location, Jordan (Figure 1A) [53]. The high alkalinity of the solution is provided by calcium and is related to the dissolution of Ca-bearing minerals. Geochemical comparison of protolith (anorthite-pyroxene hornfels) and zeolite-bearing rocks indicates enrichment of alteration products in $\mathrm{Ca}$ and $\mathrm{Cr}$ (Figure 3). The zeolitization process is fixing $\mathrm{Ca}$ [54]. Cr shows high solubility in alkaline and ultra-alkaline solutions, a phenomenon which is also typical for the Hatrurim Complex [55]. Consequently, water-rock interaction enriched and cemented zeolite-bearing rock by calcite and Cr-containing hydrous minerals.

A former study revealed that the most common zeolites are gismondine-Ca, thomsonite$\mathrm{Ca}$, and phillipsite-Ca. Additional zeolites that were identified in the "olive unit" are scolecite, mesolite, harmotome, and representatives of heulandite, harmotome, chabazite, and lévyne series [7]. Gross also found epistilbite-encrusting amygdules in other rock types of the Mottled Zone. In the studied zeolite-bearing rocks, the major revealed zeolite minerals are gismondine-Ca, thomsonite-Ca, and phillipsite-Ca. Clinoptilolite-Ca is related to calcite veins. All zeolites chiefly contain calcium, characteristic of a siliceous-poor system [50]. Phillipsite and clinoptilolite commonly occur in sedimentary rocks, whereas thomsonite-Ca, gismondine-Ca, and garronite-Ca are known to relate to hydrothermal origin [56]. Some of the thomsonite-Ca grains are enriched in Sr. Preferential concentration of $\mathrm{Sr}$ was reported for natural zeolite minerals, including thomsonite [57].

The age of zeolitization is unknown. Several interglacial periods between 250 and $30 \mathrm{Ka}$ or weathering during the wet period in the Levant between 6.3 and 3.3 Ka BP may be relevant to this process. In both cases, the zeolitic mantle persists for almost $5 \mathrm{Ka}$.

Zeolitic materials are utilized for construction uses and radioactive waste disposal. Hence, it was important to study the mechanical parameters of natural zeolite-bearing rocks that formed at least $5 \mathrm{Ka}$ before. There are two different sets of mechanical parameters for porosity below and above $24 \%$. Samples with $n<24 \%$ exhibit larger values of mechanical properties (peak axial stress, cohesion, friction angle, point load index, and Brazilian tensile strength) than samples with $n>24 \%$. Values of the point load index $\left(\mathrm{I}_{\mathrm{d}}\right)$, tensile (Brazilian) strength $\left(\sigma_{t}\right)$, cohesion $(c)$, and friction angle $(\Phi)$ obtained for all studied samples are 0.86-3.35 MPa, 2-4.29 MPa, 4.7-4.96 MPa, and 29.9-44 ${ }^{\circ}$, respectively. Elastic modulus (E) ranges from 5.36 MPa to $15.25 \mathrm{MPa}$, and Poisson's ratio (v) is between 0.11 and 0.21 .

A natural Nižný Hrabovec zeolite rock, Slovakia [58], exhibits grain density of $\mathrm{p}_{\mathrm{g}}=2.28 \mathrm{~g} / \mathrm{cm}^{3}$, porosity $(n)=25 \%$, and compressive strength $(\sigma)=33 \mathrm{MPa}$. The compressive strength of zeolite blended mortars is in the range of 32-85 MPa [54,59-65]. The compressive strength of an ordinary Portland mortar is up to $70 \mathrm{MPa}$ [66]. Commonly, zeolite-blended mortar shows a reduction of compressive strength compared to conventional mortar, but reductions decrease considerably with aging [67]. We obtained the data on a natural carbonated zeolite-bearing mortar. The geomechanics data on the zeolitebearing rock of the Hatrurim Basin do not diverge significantly. Indeed, in our study: $\mathrm{p}_{\mathrm{g}}=2.5 \mathrm{~g} / \mathrm{cm}^{3}, 19.7 \%<n<26.9 \%$ and maximum uniaxial compressive strength $(\sigma)$ at $n<24 \%$ is $28.3 \mathrm{MPa}$.

Summing up, the obtained chemical-mineralogical results of the zeolite-bearing rocks make them similar to carbonated zeolite-blended Portland mortar. The analogy between 
the Hatrurim pyrometamorphic rocks and concretes and cement was made previously. The mineralogy and composition of high-temperature spurrite-, gehlenite- and larnite-bearing marbles are similar to that of the Portland cement and belite (the synthetic counterpart of larnite) sulfoaluminate cement [52,68-70]. The products of their low-temperature alteration are similar to carbonated Portland mortars [52,69]. Products of low-temperature alteration of gehlenite-bearing marbles, katoite-bearing rocks, also resemble belite sulfoaluminate mortar [70].

\section{Conclusions}

This study reports zeolite occurrence in an unusual type of geological environment. Anorthite-pyroxene hornfels of pyrometamorphic genesis were subjected to zeolitization. The high alkalinity of the system was provided by the interaction of meteoric waters with pyrometamorphic rocks resembling Portland cement material. The estimated volume content of mineral species in zeolite-bearing rocks is: calcite, 30-40\%; opal, 2-18\%; zeolites, 18-30\%; garnet, 3-17\%; and pyroxene, 18-25\%. The zeolite-group minerals are calcic: thomsonite, phillipsite, gismondine, and clinoptilolite.

Natural zeolite-bearing rocks of the Hatrurim Basin are stable for corrosion in the desert climate of the Judean Mountains for at least $5 \mathrm{Ka}$. The zeolite-bearing blocks sampled at the surface show mechanical characteristics comparable to zeolite-blended mortar.

Author Contributions: Conceptualization: Y.V. and V.P.; data curation, methodology, resources, software, investigation, visualization, writing, and editing: Ł.K., V.P., Y.V., K.N., K.B. and I.G.; supervision: Y.V.; funding acquisition: I.G. All authors have read and agreed to the published version of the manuscript.

Funding: This research was partially supported by research project No. UMO-2013/11/B/ST10/00272 of the National Science Centre of Poland.

Data Availability Statement: Data are not subject to access restrictions.

Acknowledgments: Israeli partners are thankful for the possibility to use the equipment of the Rock Mechanic Laboratory, BGU.

Conflicts of Interest: The authors declare no conflict of interest.

\section{References}

1. Iijama, A. Geology of natural zeolites and zeolitic rocks. In Proceedings of the 5th International Conference on Zeolites, Naples, Italy, 2-6 June 1980; Rees, L.V.C., Ed.; John Wiley \& Sons: Hoboken, NJ, USA, 1980; Volume 52, pp. $2115-2130$.

2. Mumpton, F.A. Commercial utilization of natural zeolites. In Industrial Minerals and Rocks; LeFond, S.J., Ed.; American Institute of Mining, Metallurgical and Petroleum Engineers Inc.: New York, NY, USA, 1983; pp. 1418-1431.

3. Utada, M. Zeolites in Hydrothermally Altered Rocks. In Natural Zeolites: Occurrence, Properties, Applications; Bish, D.L., Ming, D.W., Eds.; Mineralogical Society of America: Chantilly, VA, USA, 2001; Volume 45, pp. 305-322.

4. Scott, M.A.; Kathleen, A.C.; Dutta, P.K. Handbook of Zeolite Science and Technology; CRC Press: New York, NY, USA, 2003 ; p. 1204.

5. Hall, A. Zeolitization of volcaniclastic sediments: The role of temperature and pH. J. Sed. Res. 1998, 68, 739-745. [CrossRef]

6. Mariner, R.H.; Surdam, R.C. Alkalinity and formation of zeolites in saline alkaline lakes. Science 1970, 170, 977-980. [CrossRef]

7. Gross, S. The mineralogy of the Hatrurim Formation, Israel. Geol. Survey Isr. Bull. 1977, 70, 80.

8. Nowak, K.; Cametti, G.; Galuskina, I.O.; Vapnik, Y.; Galuskin, E.V. Gismondine-Sr, IMA2021-043. CNMNC Newsletter 63. In Mineralogical Magazine; Cambridge University Press: Cambridge, UK, 2021; Volume 85.

9. Vapnik, Y.; Galuskina, I.; Palchik, V.; Sokol, E.V.; Galuskin, E.; Lindsley-Griffin, N.; Stracher, G.B. Stone-tool workshops of the Hatrurim Basin, Israel. In Coal and Peat Fires: A Global Perspective 3; Stracher, G.B., Prakash, A., Sokol, E.V., Eds.; Elsevier: Amsterdam, The Netherlands, 2015; pp. 281-316.

10. Novikov, I.; Vapnik, Y.; Safonova, I. Mud volcano origin of the Mottled Zone, South Levant. Geosci. Front. $2013,4,597-619$. [CrossRef]

11. Hirsch, F.; Burg, A.; Avni, Y. Arad, Sheet 15-IV, Geological Map of Israel, State of Israel, Ministry of National Infrastructures; Geological Survey: Jerusalem, Israel, 2008.

12. Sharygin, V.V.; Vapnik, Y.; Sokol, E.V.; Kamenetsky, V.S.; Shagam, R. Melt inclusions in minerals of schorlomite-rich veins of the Hatrurim Basin, Israel: Composition and homogenization temperatures. In Proceedings of the ACROFI I, Program with Abstracts, Nanjing, China, 26-28 May 2006; Ni, P., Li, Z., Eds.; Elsevier: Amsterdam, The Netherlands, 2016 ; pp. 189-192. 
13. Bentor, Y.K.; Gross, S.; Kolodny, Y. New evidence on the origin of the high temperature mineral assemblage of the "Mottled Zone" (Israel). In Proceedings of the 24th International Geology Congress, Montreal, QC, Canada, 21-23 August 1972; Section 2. pp. 265-275.

14. mindat.org. Available online: www.mindat.org (accessed on 14 September 2021).

15. Galuskin, E.V.; Krüger, B.; Galuskina, I.O.; Krüger, H.; Vapnik, Y.; Pauluhn, A.; Olieric, V. Levantite, $\mathrm{KCa}_{3}\left(\mathrm{Al}_{2} \mathrm{Si}_{3}\right) \mathrm{O}_{11}\left(\mathrm{PO}_{4}\right)$, a new latiumite-group mineral from the pyrometamorphic rocks of the Hatrurim Basin, Negev Desert, Israel. Mineral. Mag. 2019, 83, 713-721. [CrossRef]

16. Britvin, S.N.; Murashko, M.N.; Vapnik, Y.; Polekhovsky, Y.S.; Krivovichev, S.V.; Krzhizhanovskaya, M.G.; Vereshchagin, O.S.; Shilovskikh, V.V.; Vlasenko, N.S. Transjordanite, $\mathrm{Ni}_{2} \mathrm{P}$, a new terrestrial and meteoritic phosphide, and natural solid solutions barringerite-transjordanite (hexagonal $\mathrm{Fe}_{2} \mathrm{P}-\mathrm{Ni}_{2} \mathrm{P}$ ). Am. Mineral. 2020, 105, 428-436. [CrossRef]

17. Bentor, Y.K.; Vroman, A. The Geological Map of Israel 1:100,000. Sheet 16-Mount Sdom (with Explanatory Text); Geological Survey of Israel: Jerusalem, Israel, 1960; p. 117.

18. Geller, Y.I.; Burg, A.; Halicz, L.; Kolodny, Y. System closure during the combustion metamorphic "Mottled Zone" event, Israel. Chem. Geol. 2012, 334, 25-36. [CrossRef]

19. Arkin, Y.; Nathan, Y.; Starinsky, A. Paleocene. Early Eocene environments of deposition in the northern Negev (southern Israel). Bul. Geol. Survey Isr. 1972, 56, 18.

20. Vapnik, Y.; Sharygin, V.; Sokol, E.; Shagam, R. Paralavas in a combustion metamorphic complex, Hatrurim Basin, Israel. In GSA Reviews in Engineering Geology XVIII: Geology of Coal Fires: Case Studies from Around the World; Stracher, G.B., Ed.; Geological Society of America: Boulder, CO, USA, 2007; pp. 133-153.

21. Sharygin, V.V. A hibonite-spinel-corundum-hematite assemblage in plagioclase-clinopyroxene pyrometamorphic rocks, Hatrurim Basin, Israel: Mineral chemistry, genesis and formation temperatures. Minerl. Mag. 2019, 83, 123-135. [CrossRef]

22. Gur, D.; Steinitz, G.; Kolodny, Y.; Starinsky, A.; McWilliams, M. 40Ar/39Ar dating of combustion metamorphism ("Mottled Zone", Israel). Chem. Geol. 1995, 122, 171-184. [CrossRef]

23. Kolodny, Y.; Burg, A.; Geller, Y.I.; Halicz, L.; Zakon, Y. Veins in the combusted metamorphic rocks, Israel; Weathering or a retrograde event? Chem. Geol. 2014, 385, 140-155. [CrossRef]

24. Lu, Y.; Waldmann, N.; Nadel, D.; Marco, S. Increased sedimentation following the Neolithic Revolution in the Southern Levant. Glob. Planet Chang. 2017, 152, 199-208. [CrossRef]

25. Litt, T.; Ohlwein, C.; Neumann, F.N.; Hense, A.; Stein, M. Holocene climate variability in the Levant from the Dead Sea pollen record. Quat. Sci. Rev. 2012, 49, 95-105. [CrossRef]

26. Rietveld, H.M. Line profiles of neutron powder-diffraction peaks for structure refinement. Acta Cryst. 1967, 22, 151-152. [CrossRef]

27. Palchik, V.; Hatzor, Y.H. Correlation between mechanical strength and microstructural parameters of dolomites and limestones in the Judea group. Israel. Isr. J. Earth Sci. 2000, 49, 65-79.

28. Buzgar, N.; Apopei, A.I. The Raman study of certain carbonates. AŞU Iaşi 2009, 2, 97-112.

29. Arkhipenko, D.K.; Moroz, T.N. Vibrational spectrum of natural ellestadite. Crystalogr. Rep. 1997, 42, $651-656$.

30. Penelet, G.; Leroy, G.; Rey, C.; Sombret, B.; Huvenne, J.P.; Bres, E. Infrared and Raman microspectrometry study of fluor-fluorhydroxy and hydroxy-apatite powders. J. Mater. Sci. Mater. Med. 1997, 8, 271-276. [CrossRef]

31. Smallwood, A.G.; Thomas, P.S.; Ray, A.S. Characterization of sedimentary opals by Fourier transform Raman spectroscopy. Spectrochim. Acta A Molec. Biomolec. Spectr. 1997, 53, 2341-2345. [CrossRef]

32. Ilieva, A.; Mihailova, B.; Tsintsov, Z.; Petrov, O. Structural state of microcrystalline opals: A Raman spectroscopic study. Am. Mineral. 2007, 92, 1325-1333. [CrossRef]

33. Kolesov, B.A.; Geiger, C.A. The vibrational spectrum of synthetic hydrogrossular (katoite) $\mathrm{Ca}_{3} \mathrm{Al}_{2}\left(\mathrm{O}_{4} \mathrm{H}_{4}\right)_{3}$ : A low-temperature IR and Raman spectroscopic study. Am. Mineral. 2005, 90, 1335-1341. [CrossRef]

34. Buzatu, A.; Buzgar, N. The Raman study of single-chain silicates. AŞU Iaşi 2010, 56, 107-125.

35. Ma, C.; Simon, S.B.; Rossman, G.R.; Grossman, L. Calcium Tschermak's pyroxene, $\mathrm{CaAlAlSiO}_{6}$, from the Allende and Murray meteorites: EBSD and micro-Raman characterization. Am. Mineral. 2009, 94, 1483-1486. [CrossRef]

36. Huang, E.; Chen, C.H.; Huang, T.; Lin, E.H.; Xu, J. Raman spectroscopic characteristics of Mg-Fe-Ca pyroxenes. Am. Mineral. 2000, 85, 473-479. [CrossRef]

37. Wopenka, B.; Freeman, J.J.; Nikischer, T. Raman spectroscopic identification of fibrous natural zeolites. Appl. Spectr. 1998, 52, 54-63. [CrossRef]

38. Mozgawa, W. The relation between structure and vibrational spectra of natural zeolites. J. Mol. Struct. 2001, 596, 129-137. [CrossRef]

39. Armbruster, T.; Gunter, M.E. Crystal structure of natural zeolites. In Natural Zeolites: Occurrence, Properties, Applications. Reviews in Mineralogy and Geochemistry; Bish, D.L., Mind, D.W., Eds.; Mineralogical Society of America: Chantilly, VA, USA, 2001; Volume 45, pp. 1-57.

40. David, C.; Menendez, B.; Bernabe, Y. The mechanical behavior of synthetic sandstone with varying cement content. Int. J. Rock Mech. Min. Sci. Geomech. Abst. 1998, 35, 759-770. [CrossRef]

41. Digby, P.J. The effective elastic moduli of porous granular rocks. J. Appl. Mech. 1981, 48, 803-808. [CrossRef]

42. Roehl, P.O.; Choquette, P.W. Introduction. Carbonate Petroleum Reservoirs; Springer: Berlin/Heidelberg, Germany; New York, NY, USA, 1985; pp. 1-15. 
43. Mazullo, S.J.; Chilingarian, G.V.; Bissell, H.J. Carbonate Rock Classification. Carbonate Reservoirs Characterization: A GeologicalEngineering Analysis. Part 1; Elsevier: Amsterdam, The Netherlands, 1992; pp. 59-108.

44. Durrast, H.; Siegesmund, S. Correlation between rock fabrics and physical properties of carbonate reservoir rocks. Int. J. Earth Sci. 1999, 88, 392-408. [CrossRef]

45. Palchik, V. Application of Mohr-Coulomb failure theory to very porous sandy shales. Intern. J. Rock Mech. Mining Sci. 2006, 43, 1153-1162. [CrossRef]

46. Skepton, A.W. A study of immediate triaxial test on cohesive soils. In Proceedings of the 2nd International Conference on Soil Mechanics and Foundation Engineering, Rotterdam, The Netherlands, 21-30 June 1948; pp. 192-196.

47. Nash, K. The shearing resistance of fine closely graded sand. In Proceedings of the 3rd International Conference on Soil Mechanics and Foundation Engineering 1, Zurich, Switzerland, 16-27 August 1953; pp. 160-164.

48. Shinohara, K. Fundamental properties of powders. Part 1: Rheological properties of particulate solids. In Handbook of Powder Science and Technology; Fayed, M.E., Olten, L., Eds.; Van Nostrand Reinhold Co.: New York, NY, USA, 1984; Chapter 5; pp. 129-169.

49. Bevilacqua, P.; Ferrara, G. Comminution of porous materials. Int. J. Mineral. Process. 1996, 44-45, 117-131. [CrossRef]

50. Hay, R.L. Geologic occurrence of zeolites. In Natural Zeolites. Occurrence, Properties, Use; Sand, L.B., Mumpton, F.A., Eds.; Pergamon Press: Oxford, UK, 1976; pp. 135-144.

51. Hay, R.L.; Sheppard, R.A. Occurrence of zeolites in sedimentary rocks: An overview. Rev. Miner. Geochem. 2001, 45, 217-234. [CrossRef]

52. Kolodny, Y. Natural cement factory: A geological story. In Cement Production and Use; Skalny, J., Ed.; Franklin Pierce College: Rindge, NH, USA, 1979; pp. 203-216.59.

53. Clark, I.D.; Fritz, P.; Seidlitz, H.K.; Trimborn, P.; Milodowski, T.M.; Pearce, J.M.; Khoury, H.N. Recarbonation of metamorphosed marls, Jordan. Appl. Geochem. 1993, 8, 473-481. [CrossRef]

54. Colella, C.; Gennaro, M.; Aiello, R. Use of zeolitic tuff in the building industry. Rev. Miner. Geochem. 2001, 45, 551-587. [CrossRef]

55. Sokol, E.V.; Gaskova, O.I.; Kokh, S.N.; Kozmenko, O.A.; Seryotkin, Y.V.; Vapnik, Y.; Murashko, M.N. Chromatite and its Cr ${ }^{3+}$ - and $\mathrm{Cr}^{6+}$-bearing precursor minerals from the Nabi Musa Mottled Zone complex, Judean Desert. Am. Mineral. 2011, 96, 659-674. [CrossRef]

56. Gottardi, G.; Galli, E. Natural Zeolites. Minerals and Rocks Series; Springer: Berlin/Heindelberg, Germany; New York, NY, USA; Tokyo, Japan, 1985; Volume 18, p. 409.

57. Fridriksson, T.; Arnórsson, S.; Bird, D.K. Processes controlling Sr in surface and ground waters of Tertiary tholeiitic flood basalts in Northern Iceland. Geochem. Cosmochim. Acta 2009, 73, 6727-6746. [CrossRef]

58. Janotka, I.; Kvajči, L.; Dzivák, M. Properties and utilization of zeolite-blended Portland cements. Clays Clay Min. 2003, 51, 616-624. [CrossRef]

59. Ramezanianpour, A.A.; Kazemian, A.; Sarvari, M.; Ahmadi, B. Use of natural zeolite to produce self-consolidating concrete with low Portland cement content and high durability. J. Matter. Civ. Eng. 2013, 25, 589-596. [CrossRef]

60. Chen, Y.; Liu, P.; Yu, Z. Effects of environmental factors on concrete carbonation depth and compressive strength. Materials 2018, 11, 2167. [CrossRef] [PubMed]

61. Sičáková, A.; Špak, M.; Kozlovská, M.; Kováč, M. Long-term properties of cement-based composites incorporating natural zeolite as a feature of progressive building material. Adv. Mater. Sci. Eng. 2017, 2017, 7139481. [CrossRef]

62. Vaičiukynienè, D.; Vaitkevičius, V.; Kantautas, A.; Kartoviskis, A.; Rudžionis, Ž. Blended cements produced with synthetic zeolite made from industrial by-product. Mater. Sci. 2015, 21, 136-142.

63. Raggiotti, B.B.; Positieri, M.J.; Locati, F.; Murra, J.; Marfil, S. Zeolite, study of aptitude as a natural pozzolan applied to structural concrete. J. Constr. 2015, 14, 14-20. [CrossRef]

64. Ahmadi, B.; Shekarchi, M. Use of natural zeolite as a supplementary cementitious material. Cem. Concr. Compos. 2010, 32, 134-141. [CrossRef]

65. Karakurt, C.; Topçu, İ.B. Effect of blended cements produced with natural zeolite and volcanic tuffs on sulfate resistance of concrete. In Proceedings of the 1st International Symposium on Sustainable Development, Sarajevo, Bosnia-Herzegovina, 9-10 June 2009; pp. 150-156.

66. Abd Elaty, M.A.A. Compressive strength prediction of Portland cement concrete with age using a new model. HBRC J. 2014, 10, 145-155. [CrossRef]

67. Tran, Y.T.; Lee, J.; Pawan Kumar, P.; Kim, K.; Sang Soo Lee, S.S. Natural zeolite and its application in concrete composite production. Compos. Part B 2019, 165, 354-364. [CrossRef]

68. Sokol, E.V.; Kokh, S.N.; Vapnik, Y.; Thiéry, V.; Korznova, S.A. Natural analogs of belite sulfoaluminate cement clinkers from Negev Desert, Israel. Am. Mineral. 2014, 99, 1471-1487. [CrossRef]

69. Martin, L.H.J.; Leemann, A.; Milodowski, A.E.; Mäder, U.K.; Münch, B.; Giroud, N. A natural cement analogue study to understand the long-term behavior of cements in nuclear waste repositories: Maqarin (Jordan). Appl. Geochem. 2016, 71, 20-34. [CrossRef]

70. Vapnik, Y.; Palchik, V.; Galuskina, I.; Banasik, K.; Krzykawski, T. Mineralogy, chemistry and rock mechanic parameters of katoite-bearing rock from the Hatrurim Basin, Israel. J. Afr. Earth Sci. 2018, 147, 322-330. [CrossRef] 